\title{
Actual-Waste Testing of Ultraviolet Light to Augment the Enhanced Chemical Cleaning of SRS Sludge
}

\author{
C. J. Martino \\ W. D. King \\ E. T. Ketusky
}

July 2012

Savannah River National Laboratory Savannah River Nuclear Solutions, LLC Aiken, SC 29808

Prepared for the U.S. Department of Energy under contract number DE-AC09-08SR22470. 
SRNL-STI-2011-00751

Revision 0

\section{DISCLAIMER}

This work was prepared under an agreement with and funded by the U.S. Government. Neither the U.S. Government or its employees, nor any of its contractors, subcontractors or their employees, makes any express or implied:

1. warranty or assumes any legal liability for the accuracy, completeness, or for the use or results of such use of any information, product, or process disclosed; or

2. representation that such use or results of such use would not infringe privately owned rights; or

3. endorsement or recommendation of any specifically identified commercial product, process, or service.

Any views and opinions of authors expressed in this work do not necessarily state or reflect those of the United States Government, or its contractors, or subcontractors.

\section{Printed in the United States of America \\ Prepared for \\ U.S. Department of Energy}


Keywords: Tank Cleaning,

Ozone, UV, Oxalic Acid,

Retention: Permanent

\title{
Actual-Waste Testing of Ultraviolet Light to Assist Enhanced Chemical Cleaning of SRS Sludge
}

\author{
C. J. Martino \\ W. D. King \\ E. T. Ketusky
}

July 2012

Savannah River National Laboratory Savannah River Nuclear Solutions, LLC Aiken, SC 29808

Prepared for the U.S. Department of Energy under contract number DE-AC09-08SR22470. 


\section{REVIEWS AND APPROVALS}

AUTHORS:

C. J. Martino, Advanced Characterization and Processing

Date

W. D. King, Advanced Characterization and Processing

Date

E. T. Ketusky, SRR Closure Project Engineering

Date

TECHNICAL REVIEW:

M. S. Hay, Advanced Characterization and Processing

Date

\section{APPROVALS:}

F. M. Pennebaker, Manager

Date

Advanced Characterization and Processing

S. L. Marra, Manager

Date

Environmental \& Chemical Process Technology Research Programs

C. B. Sherburne, SRR Closure Project Engineering

Date

R. H. Spires, Manager

Date

SRR Closure Project Management 


\section{EXECUTIVE SUMMARY}

In support of Savannah River Site (SRS) tank closure efforts, the Savannah River National Laboratory (SRNL) conducted Real Waste Testing (RWT) to evaluate Enhanced Chemical Cleaning (ECC), an alternative to the baseline $8 \mathrm{wt} \%$ oxalic acid (OA) chemical cleaning technology for tank sludge heel removal. ECC utilizes a more dilute OA solution (2 wt\%) and an oxalate destruction technology using ozonolysis with or without the application of ultraviolet (UV) light.

SRNL conducted tests of the ECC process using actual SRS waste material from Tanks $5 \mathrm{~F}$ and $12 \mathrm{H}$. The previous phase of testing involved testing of all phases of the ECC process (sludge dissolution, OA decomposition, product evaporation, and deposition tank storage) but did not involve the use of UV light in OA decomposition. The new phase of testing documented in this report focused on the use of UV light to assist OA decomposition, but involved only the OA decomposition and deposition tank portions of the process.

Compared with the previous testing at analogous conditions without UV light, OA decomposition with the use of UV light generally reduced time required to reach the target of $<100 \mathrm{mg} / \mathrm{L}$ oxalate. This effect was the most pronounced during the initial part of the decomposition batches, when $\mathrm{pH}$ was $<4$. For the later stages of each OA decomposition batch, the increase in OA decomposition rate with use of the UV light appeared to be minimal. Testing of the deposition tank storage of the ECC product resulted in analogous soluble concentrations regardless of the use or non-use of UV light in the ECC reactor. 


\section{TABLE OF CONTENTS}

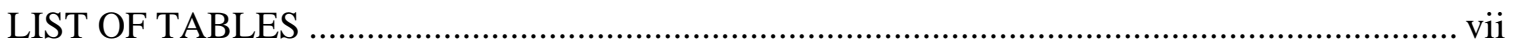

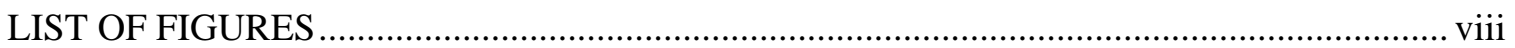

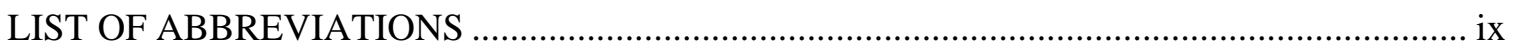

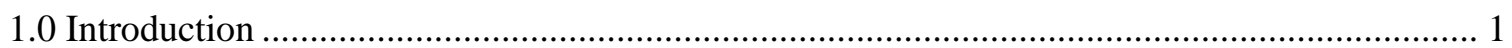

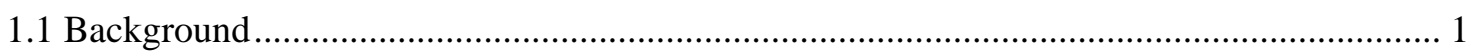

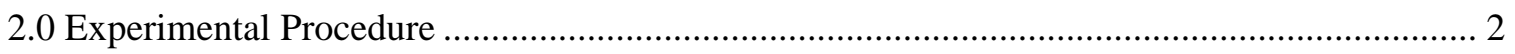

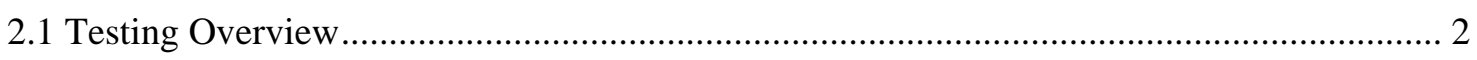

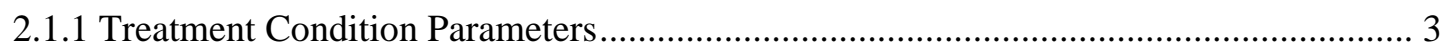

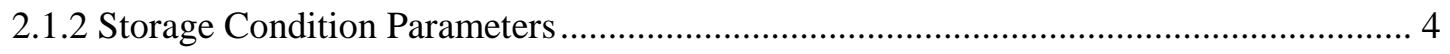

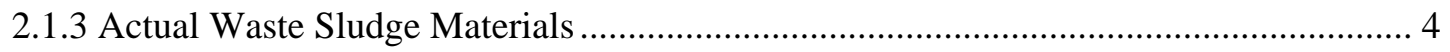

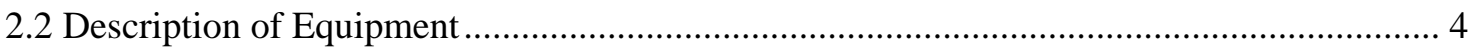

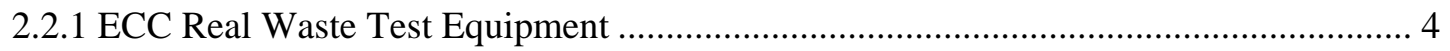

2.2.2 RWT Equipment and Measurement Calibrations ....................................................... 7

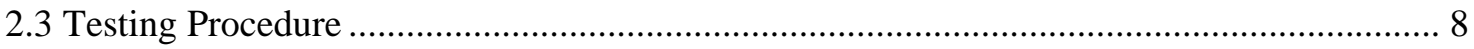

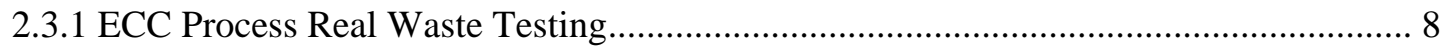

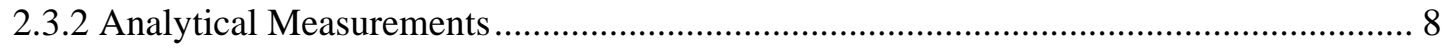

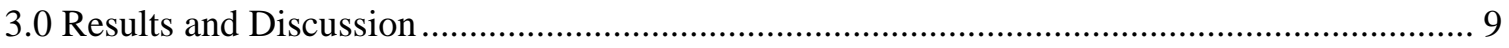

3.1 Initial Sludge Preparation and Characterization .................................................................. 9

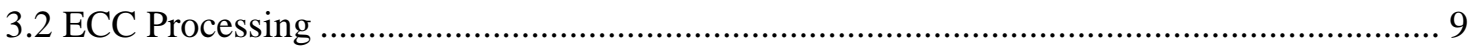

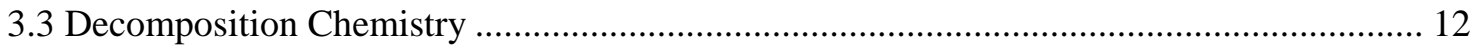

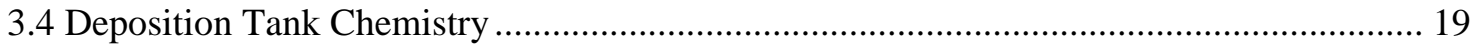

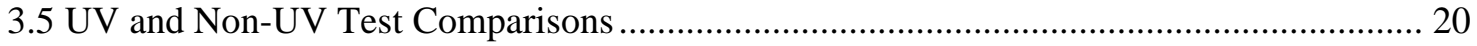

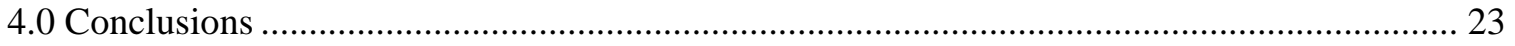

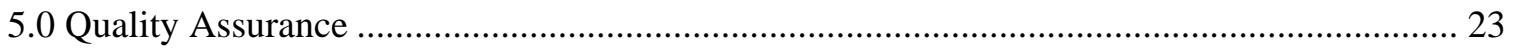

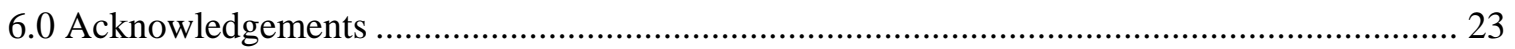

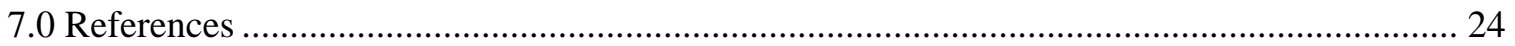

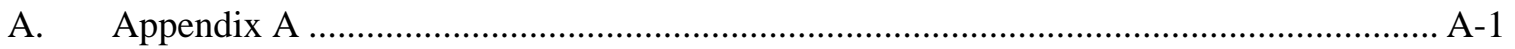




\section{LIST OF TABLES}

Table 2-1: Treatment Test Matrix

Table 3-1: Soluble Components throughout ECC Oxalate Decomposition: Test 3 (Tank 12H) OA Batch 1

Table 3-2: Soluble Components throughout ECC Oxalate Decomposition: Test 3 (Tank 12H) OA

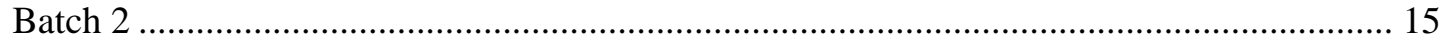

Table 3-3: Soluble Components throughout ECC Oxalate Decomposition: Test 4 (Tank 5F) OA

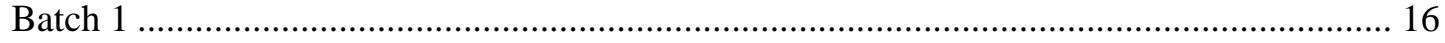

Table 3-4: Soluble Components throughout ECC Oxalate Decomposition: Test 4 (Tank 5F) OA

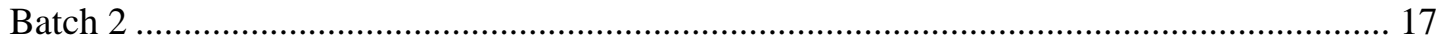

Table 3-5: Decomposition Module Feed and Product Slurry Analysis ........................................ 18

Table 3-6: Deposition Tank Supernate Chemistry for ECC Actual Waste Tests 3 and 4 ............ 19

Table A-1: Test 3 (Tank 12H Sludge) OA Batch 1 Decomposition Module Data..................... A-2

Table A-2: Test 3 (Tank 12H Sludge) OA Batch 2 Decomposition Module Data...................... A-4

Table A-3: Test 4 (Tank 5F Sludge) OA Batch 1 Decomposition Module Data ....................... A-5

Table A-4: Test 4 (Tank 5F Sludge) OA Batch 2 Decomposition Module Data ....................... A-7 


\section{LIST OF FIGURES}

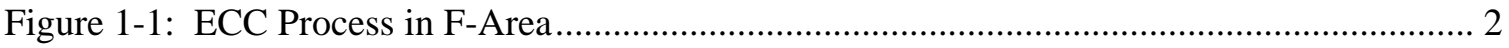

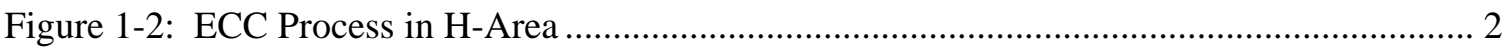

Figure 2-1: ECC RWT Equipment in Mockup Cell, Highlighting Decomposition Module.......... 5

Figure 2-2: Schematic of ECC RWT Equipment Main Cells Skid Decomposition Module (roughly related to the equipment elevation photograph of Figure 2-1) ................................. 6

Figure 3-1: Trends for pH and ORP during Decomposition Test 3 (Tank 12H) OA Batch 1...... 10

Figure 3-2: Trends for pH and ORP during Decomposition Test 3 (Tank 12H) OA Batch 2...... 11

Figure 3-3: Trends for $\mathrm{pH}$ and ORP during Decomposition Test 4 (Tank 5F) OA Batch 1 ........ 11

Figure 3-4: Trends for pH and ORP during Decomposition Test 4 (Tank 5F) OA Batch 2 ........ 12

Figure 3-5: Comparison of $\mathrm{pH}$ change during UV and no-UV light tests for Tank 5F Tests,

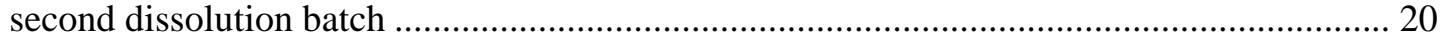

Figure 3-6: Soluble plutonium observed after sludge dissolution and after oxalate decomposition, compared with no-evaporation decomposition tank measurements....................................... 21

Figure 3-7: Soluble uranium observed after sludge dissolution and after oxalate decomposition, compared with no-evaporation decomposition tank measurements...................................... 22

Figure 3-8: UV light after Test 4 Batch 2, prior to cleaning .................................................... 22 


\section{LIST OF ABBREVIATIONS}

$\begin{array}{ll}\text { CP } & \text { Valve prefix } \\ \text { CV AA } & \text { Cold Vapor Atomic Adsorption } \\ \text { ECC } & \text { Enhanced Chemical Cleaning } \\ \text { FM } & \text { Flow Measurement prefix } \\ \text { HDPE } & \text { High Density Polyethylene } \\ \text { HLW } & \text { High-Level Waste } \\ \text { IC } & \text { Ion Chromatography } \\ \text { ICP-ES } & \text { Inductively Coupled Plasma -- Emission Spectroscopy } \\ \text { ICP-MS } & \text { Inductively Coupled Plasma -- Mass Spectrometry } \\ \text { M\&TE } & \text { Measurement and Test Equipment } \\ \text { NIST } & \text { National Institute for Standards and Technology } \\ \text { OA } & \text { oxalic acid } \\ \text { ODU } & \text { Ozone Destruction Unit } \\ \text { ORP } & \text { Oxidation / Reduction Potential } \\ \text { PI } & \text { Pressure Indicator prefix } \\ \text { PMP } & \text { Polymethylpentene } \\ \text { PuTTA } & \text { Plutonium separation by thenoyltrifluoracetone } \\ \text { RWT } & \text { Real Waste Testing } \\ \text { SC } & \text { Storage Condition } \\ \text { SRNL } & \text { Savannah River National Laboratory } \\ \text { SRR } & \text { Savannah River Remediation } \\ \text { SRS } & \text { Savannah River Site } \\ \text { TI } & \text { Temperature Indicator prefix } \\ \text { TOC } & \text { Total Organic Carbon } \\ \text { TTQAP } & \text { Task Technical and Quality Assurance Plan } \\ \text { TTR } & \text { Technical Task Request } \\ \text { UV } & \end{array}$




\subsection{Introduction}

Forty three of the High Level Waste (HLW) tanks at the Savannah River Site (SRS) have internal structures that hinder removal of the last approximately five thousand gallons of waste sludge solely by mechanical means. Chemical cleaning can be utilized to dissolve the sludge heel with oxalic acid (OA) and pump the material to a separate waste tank in preparation for final disposition. ${ }^{1,2}$ This dissolved sludge material is $\mathrm{pH}$ adjusted downstream of the dissolution process, precipitating the sludge components along with sodium oxalate solids. The large quantities of sodium oxalate and other metal oxalates formed impact downstream processes by requiring additional washing during sludge batch preparation and increasing the amount of material that must be processed in the tank farm evaporator systems and the Saltstone Processing Facility. Enhanced Chemical Cleaning (ECC) was identified as a potential method for greatly reducing the impact of oxalate additions to the SRS Tank Farms without adding additional components to the waste that would significantly alter waste composition, extend processing times, or increase waste form volumes. ${ }^{3,4}$

In support of Savannah River Site (SRS) tank closure efforts, the Savannah River National Laboratory (SRNL) conducted Real Waste Testing (RWT) to evaluate an alternative to the baseline 8 wt. \% OA chemical cleaning technology for tank sludge heel removal. The baseline OA technology results in the addition of significant volumes of oxalate salts to the SRS tank farm, with insufficient space to accommodate the $\mathrm{pH}$-adjusted streams resulting from the treatment of the multiple remaining waste tanks requiring closure.

ECC is a promising alternative to bulk OA cleaning, utilizing a more dilute OA solution (nominally $2 \mathrm{wt}$. \% at a $\mathrm{pH}$ of around 2) combined with an oxalate destruction technology. The technology is being adapted by AREVA from their decontamination technology for Nuclear Power Plant secondary side scale removal.

The overall goals for SRNL RWT are as follows:

- to confirm ECC performance with real tank sludge samples,

- to determine the impact of ECC on fate of actinides and the other sludge metals, and

- to determine changes, if any, in solids flow and settling behavior.

A Task Technical and Quality Assurance Plan (TTQAP) ${ }^{5}$ details the experimental plan as outlined by the Technical Task Request (TTR). ${ }^{6}$ A previous report contained results from the SRNL small scale testing of the ECC process using SRS sludge tank sample material. ${ }^{7}$ The previous testing included tests of the full process (sludge dissolution with 2 wt \% OA, decomposition of oxalates by ozonolysis, the evaporation of precipitated sludge, and storage in the deposition tank). This report contains follow-up testing on utilizing ultraviolet light to augment the ozonolysis process for the decomposition of oxalates. In contrast to the previous testing, this testing focuses on the changes that occur during the decomposition unit operation.

\subsection{Background}

The ECC process supports closure of non-compliant waste tanks at SRS by removing the residual sludge heels in the tanks. Sludge is dissolved in a Treatment Tank by adding $2 \mathrm{wt} \% \mathrm{OA}$ and mixing the tank contents. This mixture of dissolved sludge and suspended insoluble solids is transferred to the ECC reactor, where the OA and other oxalates are decomposed. Concentrated 
ozone gas is added to the reactor, resulting in soluble ozone and hydroxyl radicals that decompose the oxalate ion to carbon dioxide gas and raise the $\mathrm{pH}$ of the liquid. The change in chemistry inside the ECC reactor causes the dissolved sludge to form a precipitate, mostly in the form of metal oxides/hydroxides. The supplemental use of UV light in the ECC reactor holds potential for increasing the oxalate decomposition rate but it is not included in the current baseline process design.

For F-Area tanks, the treated waste is transferred to a deposition tank where the solids will be allowed to settle, followed by water removal via the $2 \mathrm{~F}$ evaporator (Figure 1-1). The planned treatment of H-Area tanks includes a flash evaporator to recover and recycle water (Figure 1-2). Sodium hydroxide will be added in-line to both the F-Area and H-Area stream during the transfer to the deposition tank to ensure compliance with the corrosion control program requirements.

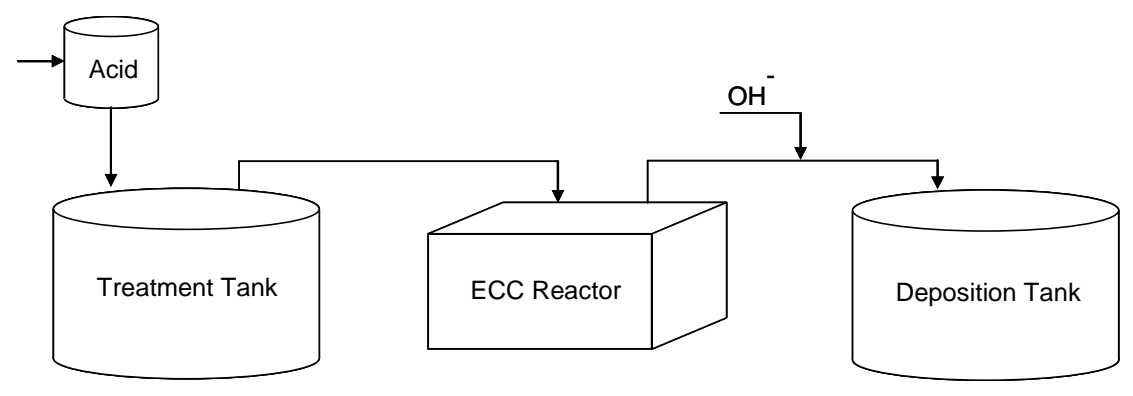

Figure 1-1: ECC Process in F-Area

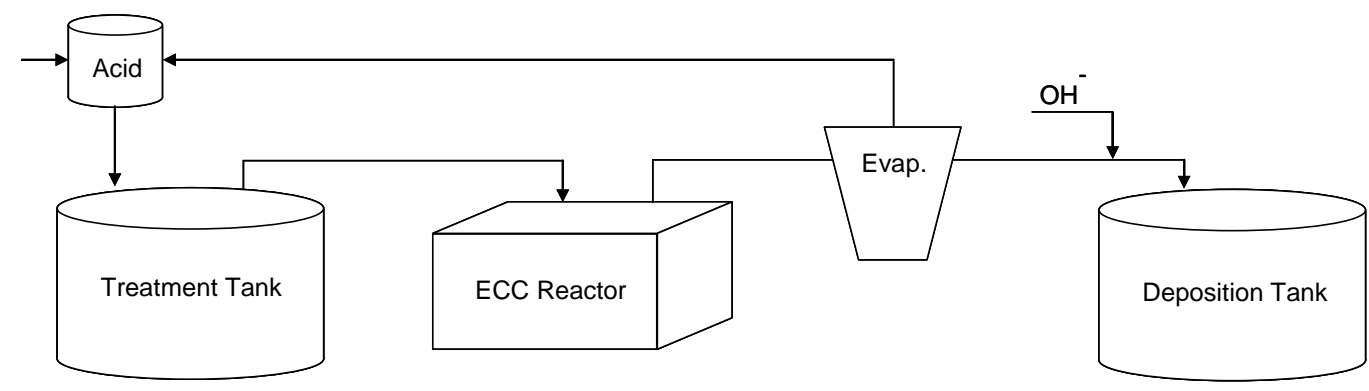

Figure 1-2: ECC Process in H-Area

\subsection{Experimental Procedure}

\subsection{Testing Overview}

The ECC RWT is designed to demonstrate the following:

- The use of ozone (with or without the use of UV light) will be effective for decomposing OA used for actual waste sludge dissolution.

- The solubility of some metals will change during the dissolution and the oxalate decomposition compared to nominal sludge storage conditions. 
- The solubilities of metals and actinides in the ECC reactor product or evaporator product will return to levels comparable with the nominal sludge storage condition when brought back into Tank Farm corrosion control compliance (via contact with tank heel material and/or $\mathrm{pH}$ adjustment with sodium hydroxide) over a time period of hours to days.

This phase of ECC RWT focuses on ECC reactor conditions utilizing UV light to supplement the process for oxalate decomposition.

The ECC RWT matrix is divided into two conceptual sections: treatment conditions and storage conditions. The treatment conditions pertain to the condition of the Decomposition Modules. Only a single storage condition was explored during this testing.

\subsubsection{Treatment Condition Parameters}

Overall, four tests were planned at various treatment conditions, as shown in Table 2-1. Tests 1 and 2, the process baseline cases without the use of UV light, were completed and reported previously. Tests 3 and 4, which use UV light to augment the decomposition of oxalate, are detailed in this report.

Table 2-1: Treatment Test Matrix

\begin{tabular}{c|c|c|c|c}
\hline Test & $\begin{array}{c}\text { Sludge } \\
\text { Feed }\end{array}$ & UV Light? & $\begin{array}{c}\text { OA } \\
\text { Batches }\end{array}$ & Included in Report \\
\hline 1 & Tank $12 H$ & No & 3 & SRNL-STI-2011-00360 \\
\hline 2 & Tank 5F & No & 3 & SRNL-STI-2011-00360 \\
\hline 3 & Tank $12 H$ & Yes & 2 & This Report \\
\hline 4 & Tank 5F & Yes & 2 & This Report \\
\hline
\end{tabular}

Dissolution Module testing was not a part of these tests. Oxalic acid and dissolved sludge mixtures that were prepared during previous Treatment Tank rheology testing were used for Tests 3 and 4 . The description of the preparation of these feed materials is contained in Ref. 7, Section 2.3.3.1. For the feeds used in Test $3,45.6$ grams of Tank $12 \mathrm{H}$ sludge was partially dissolved by contacting the material with $2.3 \mathrm{~L}$ of $70{ }^{\circ} \mathrm{C}$ OA for 7 days. For the feeds used in Test 4, 62.9 grams of Tank 5F sludge was partially dissolved by contacting the material with $2.9 \mathrm{~L}$ of $70^{\circ} \mathrm{C}$ OA for 7 days. For each test, two sequential batch contacts were performed.

Several months had passed from the completion of the Treatment Tank rheology testing and the utilization of the solutions in the ECC Reactor UV-light testing. During this time, some of the OA may have naturally decomposed. For this reason, and to provide sufficient volume of each material batch, the solutions were augmented with additional OA to bring the overall OA concentration to above the target of $2 \mathrm{wt} \%$.

The Decomposition Module was operated using the methodology recommended by AREVA and adapted as necessary by SRNL. ${ }^{8}$ The flow of ozone into the system through the eductor was balanced to the recirculation of the dissolved sludge material. The Decomposition Module operating temperature was $70{ }^{\circ} \mathrm{C}$ and the expected decomposition duration was 6 to 20 hours. The Decomposition Module vessel included measurement of temperature, $\mathrm{pH}$, and ORP. 
Throughout Decomposition Module operations, several intermediate liquid or slurry samples were collected from the recirculation loop for preparation and analysis.

The Decomposition Module was operated until the $\mathrm{pH}$ increased to above 7 and stabilized. At that point, a sample was tested with a permanganate method to confirm that the target endpoint of $100 \mathrm{ppm}$ oxalate was reached. For the RWT, the target for OA decomposition of less than 100 ppm corresponds to $99.5 \%$ oxalate decomposition.

As evident in the treatment test matrix, the following parameters were varied:

- The source of the actual waste sludge, from Tank $5 \mathrm{~F}$ or $12 \mathrm{H}$.

- The use or non-use of UV light to aid in OA decomposition

\subsubsection{Storage Condition Parameters}

At the conclusion of Decomposition Module operation, a portion of the material was transferred to a storage bottle. In contrast to the previous ECC RWT tests (Tests 1 and 2), a single storage condition was investigated for the product from Tests 3 and 4 . Each test used a single storage bottle that was held at $50{ }^{\circ} \mathrm{C}$ and adjusted to $\mathrm{pH}$ of around $14\left(1 \mathrm{M} \mathrm{OH}^{-}\right)$. After the material from both batches had been added to the storage bottle, the bottle was held at the storage conditions for 14 days. At the completion of the storage period, the bottles were agitated to resuspend solids, sampled for chemical and radiologic analysis, and the $\mathrm{pH}$ and ORP were measured.

\subsubsection{Actual Waste Sludge Materials}

Two actual-waste sludge feeds from previous tank sampling were utilized as feeds for the RWT. Tank 5F sludge material used in the test represents F-Area PUREX sludge and Tank $12 \mathrm{H}$ sludge represents H-Area HM sludge. Additional details and characterization of these materials are provided in Section 3.1 of the previous ECC RWT report. ${ }^{7}$

\subsection{Description of Equipment}

The majority of the ECC RWT was performed in SRNL Shielded Cells B-Block. The equipment simulating the ECC Reactor for the RWT was designed and provided by AREVA. The Deposition Tank and intermediate storage were provided by SRNL.

\subsubsection{ECC Real Waste Test Equipment}

The primary ECC RWT equipment was designed and fabricated by AREVA per a contract with SRR and through consultation with SRNL. The equipment design is based on the SRR Statement of Work, ${ }^{9}$ the AREVA RWT technical requirements and equipment design report, ${ }^{10}$ and the AREVA RWT project plan ${ }^{11}$ and is reflected in the Piping and Instrumentation Diagram ${ }^{12}$. Configuration and operating conditions are outlined in the Process Flow Diagram. ${ }^{8}$ 


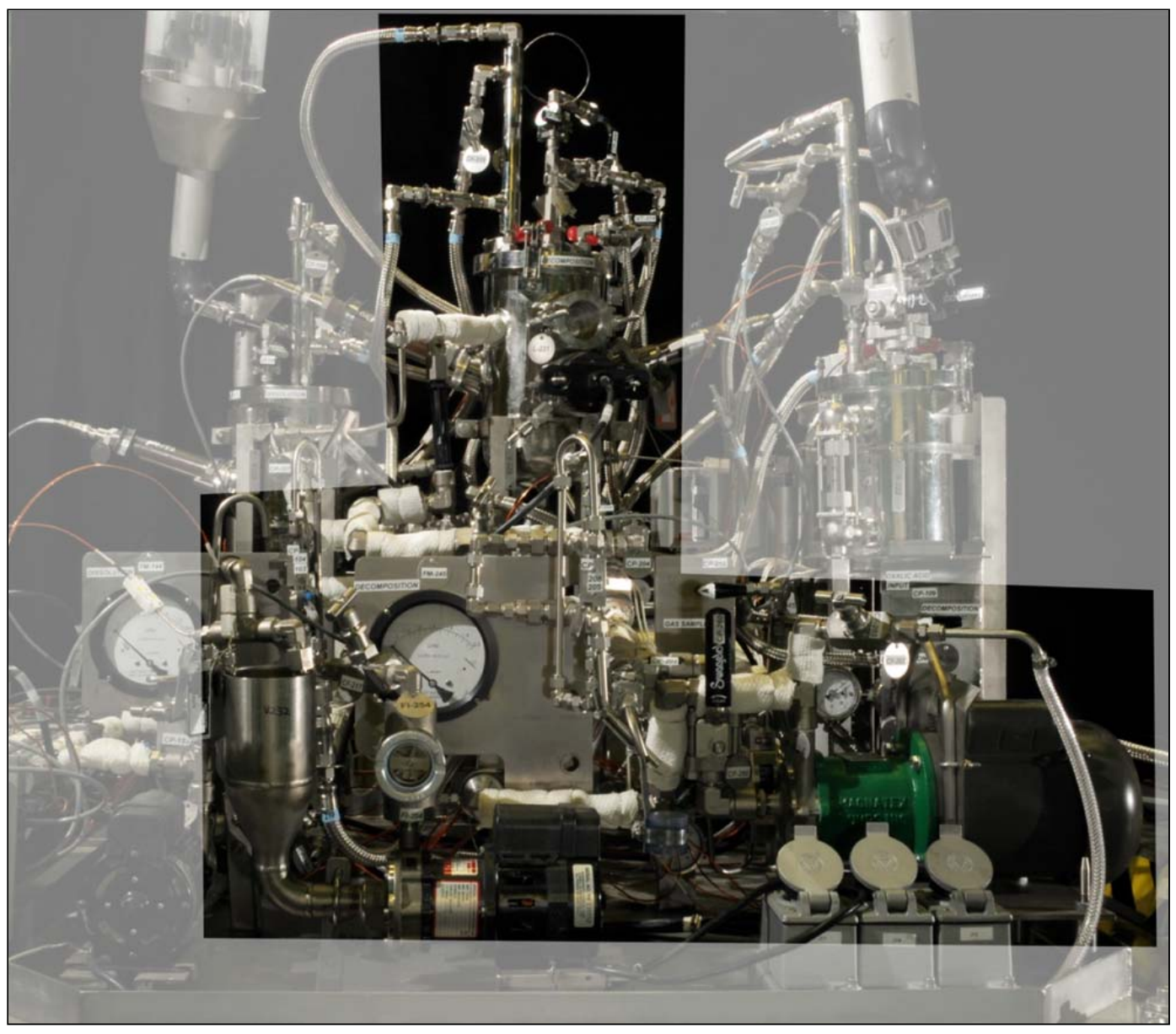

Figure 2-1: ECC RWT Equipment in Mockup Cell, Highlighting Decomposition Module 
SRNL-STI-2011-00751

Revision 0

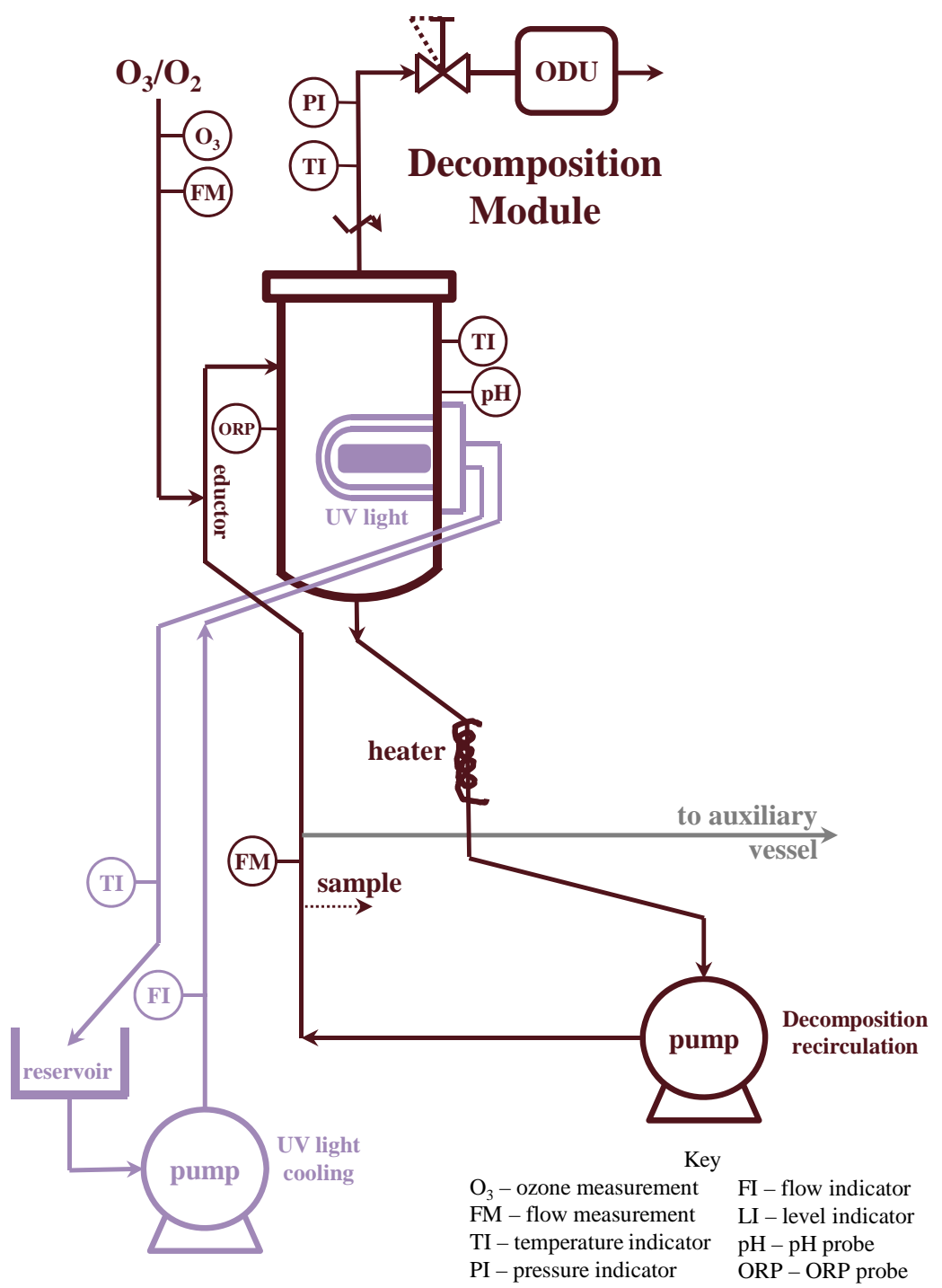

Figure 2-2: Schematic of ECC RWT Equipment Main Cells Skid Decomposition Module (roughly related to the equipment elevation photograph of Figure 2-1)

The AREVA ECC RWT equipment (Figure 2-1, and Figure 2-2) contains three primary modules, one each for 1) the dissolution of sludge from the treatment-tank (Dissolution Module), 2) the ECC ozone/UV reactor for decomposition of the oxalate (Decomposition Module), and 3) the removal of water for the recovery of dissolution fluid volume (Evaporator Module). This set of testing used only the Decomposition Module. The Decomposition Module contains a reaction loop where ozone contacts the fluid through an eductor and a vessel that allows for gas/liquid separation and the application of UV light via a medium pressure source. The Decomposition Module contains a heater to allow for reaction at $70{ }^{\circ} \mathrm{C}$ and a recirculation loop with a pump to allow for mixing, sampling, and transfer. The Decomposition Module has the ability to be operated both with and without the application of UV light to the fluid. The Decomposition Module includes a system for cleaning the UV light sheath with OA. The Decomposition Module includes probes to monitor both the fluid $\mathrm{pH}$ and the oxidation/reduction potential (ORP). Offgas is sent through an Ozone Destruction Unit (ODU) to decompose ozone to below 0.1 ppmv before 
being vented to the Shielded Cell atmosphere. An ozone generator was placed behind Shielded Cells B-Block for use in this study. Control modules for the ECC RWT equipment were accessible in the operations area in front of B-Block Cells 11 and 12. Refer to the ECC RWT equipment Piping and Instrumentation Diagram for component labeling on the AREVA-supplied equipment. ${ }^{12}$

Additional ancillary equipment was provided by SRNL. Fabrication of the service plugs for shielded cell installation was performed by SRNL. SRNL used an auxiliary vessel (a 4 L high density polyethylene (HDPE) bottle with a magnetic stir bar on a stir plate) for splitting the material leaving the Decomposition Module so that representative portions could be stored in separate deposition bottles and other portions processed in the Evaporation Module. Fluids were able to be removed from the Dissolution and Decomposition Modules of the ECC RWT equipment using ports on the recirculation loops. A peristaltic pump with tygon tubing and stainless steel dip legs was used whenever material needed to be removed from the auxiliary vessels. SRNL also provided the deposition bottles, the equipment required for holding the bottles at deposition tank temperatures, and the equipment for sampling the deposition bottles. Portions of material prior to and after evaporation were stored at Deposition Tank conditions and sampled periodically. Polymethylpentene (PMP) storage bottles were held at $50{ }^{\circ} \mathrm{C}$ in a $20 \mathrm{~L}$ water bath.

\subsubsection{RWT Equipment and Measurement Calibrations}

Many instruments involved with the ECC RWT were utilized inside of the SRNL shielded cells in radioactive service. For such equipment, it is often not practical to perform post-testing calibration in accordance with the Measurement and Test Equipment (M\&TE) program because the components become too contaminated to be submitted to the SRS Standards Laboratory. For such equipment, pre-test calibration or calibration checking was performed in accordance with the M\&TE program. Prior to removal from the shielded cells for end-of-use disposal, some M\&TE were cross checked for measurement consistency.

Thermocouples that measure the temperatures inside of the Decomposition Module (TI-240 and TI-241), UV-light cooling system (TI-255), and Deposition Bottle storage conditions underwent pre-test calibration checking and were placed in the M\&TE program. Pressure gauges PI-247, PI342 and PI-440 were calibrated and placed in the M\&TE program. Pressure Relief Valves CP444 and CP-209 were bench tested as required by SRS Pressure Safety. In-cell balances and weight sets were already part of and maintained within the M\&TE program.

The $\mathrm{pH}$ meters used on the ECC RWT Equipment and used in the Deposition Bottles were checked using $\mathrm{pH}$ buffers over an appropriate range and were done in a manner consistent with program requirements for Analytical Measurement Systems. The ORP probes were checked by Light's Solution and Zobell's Solution in a manner consistent with program requirements for Analytical Measurement Systems. Calibration checks of $\mathrm{pH}$ and ORP probes contained in ECC RWT Equipment chambers were performed prior to and after each OA batch. The potential failure of probes during testing was a known risk.

The liquid/slurry flow meter FM-245 provides flow status indication to the equipment operator but is not intended to provide precise measurement data during testing. Thus, FM-245 was not calibrated or placed in the M\&TE program. The high-concentration ozone monitor O3-441 was not calibrated or placed in the M\&TE program and was used in the condition as provided by 
AREVA. The other ambient ozone monitors (O3-443 and O3-230) were not recalibrated by SRNL because they were not used as the primary Industrial Health monitor for ozone gas.

\subsection{Testing Procedure}

\subsubsection{ECC Process Real Waste Testing}

Use of the ECC RWT equipment was governed by a Technical Reference procedure. ${ }^{13}$ Each batch of sludge dissolved in OA was nominally 2.5 L. Testing in the Decomposition Module was initiated by heating each batch of dissolved sludge to $70^{\circ} \mathrm{C}$ with a recirculation of 1.8 gallons per minute (if attainable). Once at temperature, the UV light was energized and $2 \mathrm{~L}$ per minute of a 5 wt\% ozone in oxygen stream was fed into the system with a back pressure of 8 psi. Decomposition was continued until, through a combination of $\mathrm{pH}$ measurement and permanganate end-of-process testing, it was determined that the soluble oxalate concentration was less than $100 \mathrm{ppm}$.

\subsubsection{Analytical Measurements}

References 5 and 7 list the planned analyses for each type of sample taken during the ECC RWT. The primary analytes obtained by each method are also listed, although not all analytes were detectable in every sample and some additional analytes were attainable from some of the methods without additional effort.

Samples from the recirculation loop of the Decomposition Module were either liquid or slurry depending on the stage at which sampling was performed. For some samples, the composition of the slurry was desired, but typically the composition of the soluble components in the slurry were the target. To obtain analysis of the soluble components in the slurry, the slurry was filtered through a 0.45 -micron nylon syringe filter.

During Decomposition Module operation, three intermediate samples were taken from the recirculation loop at intervals during OA decomposition. The intermediate Decomposition Module samples were filtered and the filtrate analyzed in duplicate for anions (including oxalate) by ion chromatography (IC), metals (including iron and aluminum) by inductively coupled plasma-emissions spectroscopy (ICP-ES), other radiochemical (Pu) and ionic $\left(\mathrm{CO}_{3}{ }^{2-}\right)$ components. At the end of the OA decomposition, samples were additionally analyzed for soluble gamma and Sr-90. Single aqua regia dissolutions of the Decomposition Module slurry samples were prepared and analyzed for a subset of the metal and radiochemical components.

Each test had a corresponding Deposition Tank storage bottle. The storage bottles were mixed prior to sampling, but were not mixed continuously. After two weeks, a sample was taken from each storage bottle, filtered with a 0.45 micron filter, and the filtrate prepared for analysis. Intermediate samples were filtered, acidified, and analyzed by IC, ICP-ES, ICP-MS, and radiochemistry $(\mathrm{Pu})$.

For the majority of the analytical methods, 1-sigma uncertainties are nominally $10 \%$ or less. Sample preparations were performed in a manner as not to add significantly to the overall $10 \%$ uncertainly of the analytical methods. 
As described in Reference 7, calorimetric spot tests were conducted in the shielded cells near the end of each decomposition test to confirm that the oxalate anion levels in the spent acid solution had decreased to the target level of $100 \mathrm{ppm}$. Oxalate analyses by IC ultimately confirmed that oxalate concentration of near 100 ppm or less was obtained for the decomposition tests.

\subsection{Results and Discussion}

\subsection{Initial Sludge Preparation and Characterization}

As seen from the previous characterization of the actual waste sludges used in this study, the primary component of the Tank $5 \mathrm{~F}$ sludge is iron while the primary component of the Tank $12 \mathrm{H}$ sludge is aluminum. ${ }^{7}$ Both sludge samples contain significant iron, aluminum, manganese, sodium, and uranium. Additionally, the Tank 5F sludge contains significant nickel while the Tank $12 \mathrm{H}$ sludge contains significant mercury and thorium. Both samples contain high activities of Sr-90, with significant differences in the radioactive isotope profiles between the two sludge types with respect to $\mathrm{Pu}-238, \mathrm{Pu}-239$, uranium enrichment, and other isotopes.

\subsection{ECC Processing}

The two tests during this phase of the study involved testing the ECC reactor portion of the ECC process for the decomposition of OA and the precipitation of sludge. These two tests utilize the UV-light installed in the ECC reactor in order to assist the OA decomposition process. During the previous phase of testing, ${ }^{7}$ portions of treatment tank residual sludge were prepared.

Table 2-1 contains a description of the ECC tests that were performed over the course of this program. This report contains the results of the testing performed with use of the UV light. Test 3 was conducted using Tank $12 \mathrm{H}$ sludge feed material while Test 4 used Tank 5F sludge feed material. The previous report contained results for the two tests involving OA decomposition without the use of UV light.

The material used in this testing was obtained by dissolving Tank $12 \mathrm{H}$ and 5F sludge feeds with 2 wt\% OA during previous testing for treatment tank rheology.

Appendix A contains a series of tables (Table A-1 through Table A-4) that list the process conditions as a function of time for the decomposition runs performed. Decomposition data was recorded on a 15 minute interval except for periods where $\mathrm{pH}$ readings were changing rapidly enough to warrant more frequent observation.

Figure 3-1 through Figure 3-4 contain plots of the in-process $\mathrm{pH}$ and ORP measurement data during the ECC decomposition testing. During decomposition testing, $\mathrm{pH}$ was used as the indicator of OA decomposition. The $\mathrm{pH}$ generally started low, near the final $\mathrm{pH}$ of the $\mathrm{OA}$ and dissolved sludge mixture measured at the end of the dissolution process. As the ECC decomposition proceeded, the $\mathrm{pH}$ gradually increased, accelerating as the $\mathrm{pH}$ approached 7 . The $\mathrm{pH}$ then leveled off, usually above $\mathrm{pH}$ 8. Overall, the ORP measurements were less regular than the $\mathrm{pH}$ measurements. ORP remained constant for the most part during the initial periods where 
$\mathrm{pH}$ was changing slowly. Then a change in the ORP measurement was usually noted during periods when $\mathrm{pH}$ was changing more rapidly. This period was usually followed by another period of nearly constant ORP.

Figure 3-1 and Figure 3-2 contain the $\mathrm{pH}$ and ORP trends for Test 3 (Tank 12H sludge) OA decomposition for the first and second batches, respectively. There were anomalous $\mathrm{pH}$ and ORP readings during Test 3 Batch 2. This was likely caused by the volume of liquid in the ECC reactor decreasing to a level where the probes were not submerged. The initial volume for Batch 2 was relatively small, and during the test, further volume reduction due to sampling likely caused this situation. For both Batches 1 and 2, a $\mathrm{pH}$ of 3 was attained in about 1.5 hours. After this initial period, however, the $\mathrm{pH}$ change levels off and begins a steady increase to near-neutral $\mathrm{pH}$.

Figure 3-3 and Figure 3-4 contain the $\mathrm{pH}$ and ORP trends for Test 4 (Tank 5F sludge) OA decomposition for the first and second batches, respectively. During the initial portion of each decomposition batch, $\mathrm{pH}$ increased to above 3 within the first 1.2 hours, which is significantly less time than for analogous batches without the use of UV light.

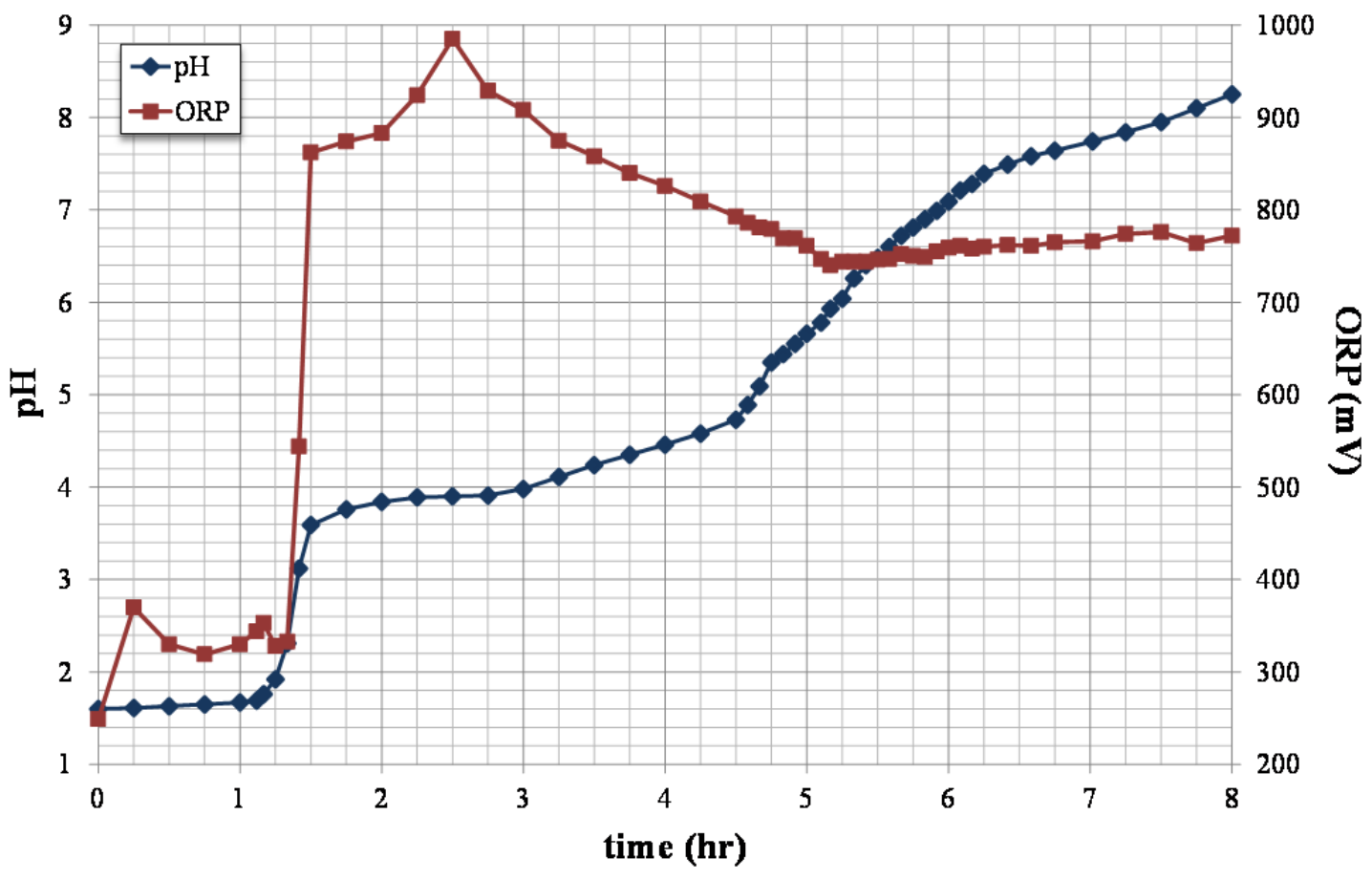

Figure 3-1: Trends for pH and ORP during Decomposition Test 3 (Tank 12H) OA Batch 1 


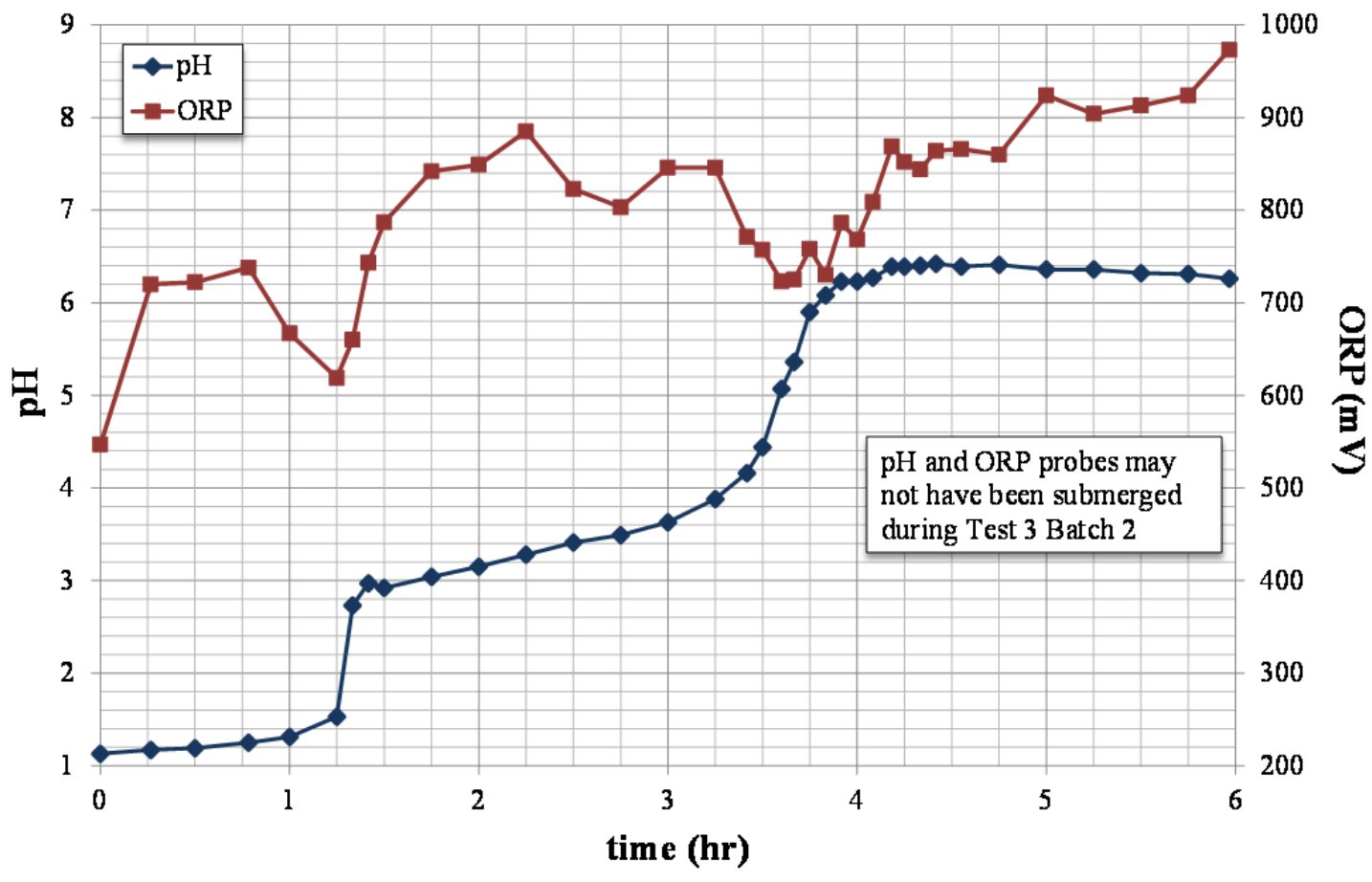

Figure 3-2: Trends for pH and ORP during Decomposition Test 3 (Tank 12H) OA Batch 2

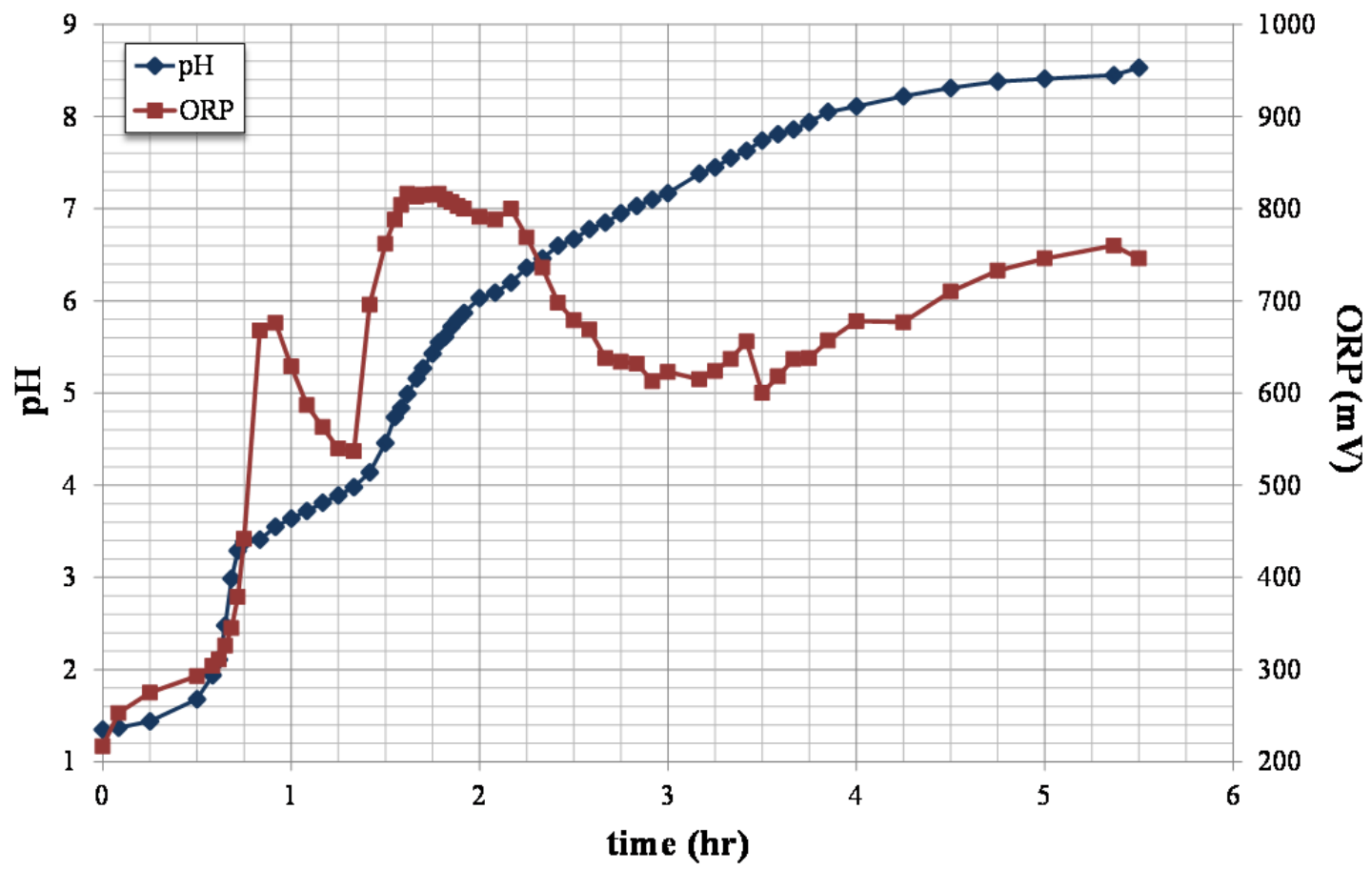

Figure 3-3: Trends for $\mathrm{pH}$ and ORP during Decomposition Test 4 (Tank 5F) OA Batch 1 


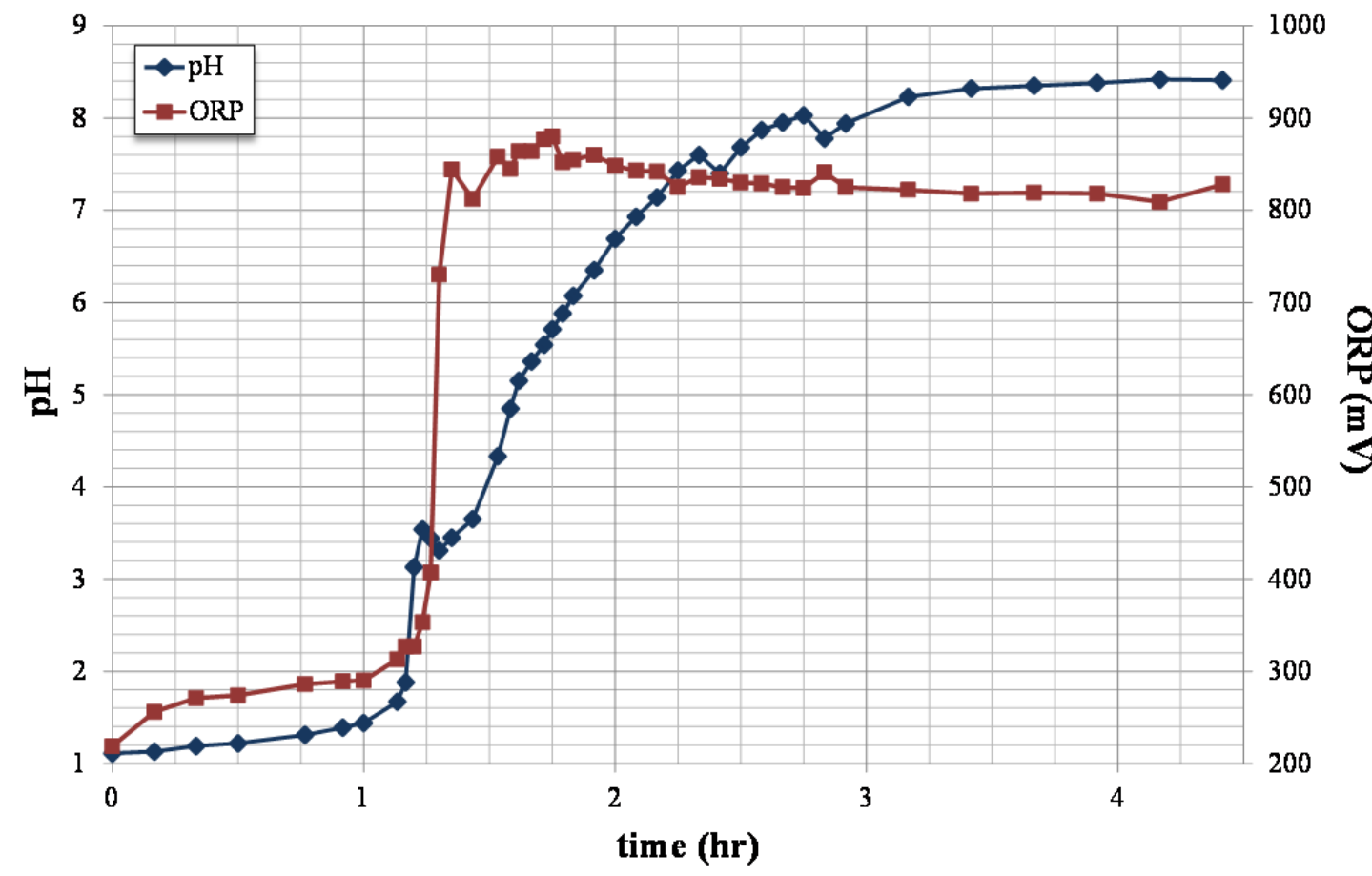

Figure 3-4: Trends for pH and ORP during Decomposition Test 4 (Tank 5F) OA Batch 2

\subsection{Decomposition Chemistry}

In this section, data is presented for the soluble and insoluble portions analyzed after the sludge dissolution process and during and after the OA decomposition process. Table 3-1 through Table 3-4 contain the results for the soluble components during OA decomposition by application of ozone and UV light at $70{ }^{\circ} \mathrm{C}$. Each table includes several columns of data that represent the composition of a series of samples taken as a function of time as the OA decomposition progressed during each batch. The column labeled "initial" shows an average of the duplicate analysis of the filtered samples of the feed to the Decomposition Module. The columns labeled "1st sample," "2nd sample," and "3rd sample" show the single analyses of the filtered intermediate Decomposition Module samples. The "final sample" is an average of the duplicate analysis of the filtered samples taken from the Decomposition Module after the $\mathrm{pH}$ and permanganate end-of-process test indicated that OA decomposition was complete. Included for reference in the Decomposition chemistry tables are the run time and the $\mathrm{pH}$ and ORP readings as the time of sampling.

In general, most sludge components show the highest soluble concentrations in the initial dissolved sludge and early decomposition samples. As the sludge components drop out of solution, subsequent decomposition samples show lower concentrations of soluble sludge components until the end of the decomposition process that typically has the lowest concentration of soluble sludge components. This is true for Fe, Al, Mn, Sr-90 and is typically true for $\mathrm{U}$ and $\mathrm{Pu}$. This behavior does not hold for typical supernate components such as sodium and Cs-137, which remain largely soluble throughout the OA decomposition. 
Compared with the non-UV light tests, there is an apparent increase (less than a factor of 2) in the utilization of ozone when UV light was used. There are several factors, however, that complicate the determination on the utilization of ozone. During later tests, the in-process measurement of ozone concentration started dropping. This caused the ozone generator to operate at $100 \%$ power (versus the typical $70 \%$ power for most testing) and portions of the testing did not involve the target $5 \mathrm{wt} \%$ ozone (sometimes as low as $2 \mathrm{wt} \%$ ozone). If the error was with the ozone generator module, less than the target amount of ozone was being fed to the system. If the error was with the ozone measurement, more than the target amount of ozone was being fed to the system. Another factor that complicates the determination of ozone utilization is that, due to a longer than desired period prior to oxalate measurement, the potential for decomposition of oxalate in the samples casts doubt on the initial oxalate composition in the feed. There is also uncertainty about the precise batch volume for each decomposition test.

Table 3-5 contains the results for the bulk analysis of the slurries at the end of the dissolution and decomposition processes for Tests 3 and 4, respectively. These results indicate the composition of the slurries within the process and are provided for reference. Ideally, the 'initial' and 'final' values for components in the slurry should be identical for components that are not being created or destroyed in order for the mass balance to close. The balance for most sludge components failed to close within $10 \%$. 
Table 3-1: Soluble Components throughout ECC Oxalate Decomposition: Test 3 (Tank 12H) OA Batch 1

\begin{tabular}{|c|c|c|c|c|c|c|}
\hline analyte & units & initial & 1st sample & 2nd sample & 3rd sample & final sample \\
\hline time & $\mathrm{hr}$ & 0.0 & 1.2 & 2.5 & 5.0 & 7.9 \\
\hline $\mathrm{pH}$ & -- & 1.65 & 3.12 & 4.11 & 6.04 & 8.55 \\
\hline ORP & $\mathrm{mV}$ & 249 & 353 & 985 & 761 & 772 \\
\hline Oxalate & $\mathrm{mg} / \mathrm{L}$ & $2.83 \mathrm{E}+04$ & $7.64 \mathrm{E}+03$ & $6.04 \mathrm{E}+03$ & $1.42 \mathrm{E}+03$ & $1.33 \mathrm{E}+02$ \\
\hline Ag & $\mathrm{mg} / \mathrm{L}$ & $<6.96 E-01$ & $<7.14 E-01$ & $<7.04 E-01$ & $<6.68 E-01$ & $<7.49 E-01$ \\
\hline $\mathrm{Al}$ & $\mathrm{mg} / \mathrm{L}$ & $1.57 \mathrm{E}+03$ & $1.56 \mathrm{E}+03$ & $7.30 \mathrm{E}+02$ & $1.38 \mathrm{E}+02$ & $<1.70 E+00$ \\
\hline B & $\mathrm{mg} / \mathrm{L}$ & $1.67 \mathrm{E}+00$ & $1.46 \mathrm{E}+00$ & $<9.73 E-01$ & $<9.24 E-01$ & $<1.04 E+00$ \\
\hline $\mathrm{Ba}$ & $\mathrm{mg} / \mathrm{L}$ & $2.78 \mathrm{E}+00$ & $2.47 \mathrm{E}+00$ & $6.00 \mathrm{E}-01$ & $<2.74 E-02$ & $<3.08 E-02$ \\
\hline $\mathrm{Ca}$ & $\mathrm{mg} / \mathrm{L}$ & $2.10 \mathrm{E}+01$ & $2.05 \mathrm{E}+01$ & $1.77 \mathrm{E}+01$ & $7.48 \mathrm{E}+00$ & 3.24E-01 \\
\hline Cd & $\mathrm{mg} / \mathrm{L}$ & $<1.52 E-01$ & $<1.57 E-01$ & $<1.54 E-01$ & $<1.46 E-01$ & $<1.64 E-01$ \\
\hline $\mathrm{Ce}$ & $\mathrm{mg} / \mathrm{L}$ & $<3.37 E+00$ & $<3.46 E+00$ & $<3.41 E+00$ & $<3.24 E+00$ & $<3.63 E+00$ \\
\hline $\mathrm{Cr}$ & $\mathrm{mg} / \mathrm{L}$ & $5.01 \mathrm{E}+00$ & $5.02 \mathrm{E}+00$ & $3.75 \mathrm{E}+00$ & $2.71 \mathrm{E}+00$ & $3.54 \mathrm{E}+00$ \\
\hline $\mathrm{Cu}$ & $\mathrm{mg} / \mathrm{L}$ & $3.07 \mathrm{E}+00$ & $2.98 \mathrm{E}+00$ & $2.39 \mathrm{E}+00$ & $1.44 \mathrm{E}+00$ & 3.86E-01 \\
\hline $\mathrm{Fe}$ & $\mathrm{mg} / \mathrm{L}$ & $3.65 \mathrm{E}+02$ & $3.08 \mathrm{E}+02$ & $9.47 \mathrm{E}+00$ & $4.84 \mathrm{E}+00$ & $<4.93 E-01$ \\
\hline Gd & $\mathrm{mg} / \mathrm{L}$ & $<1.03 E+00$ & $<1.06 E+00$ & $<1.04 E+00$ & $<9.88 E-01$ & $<1.11 E+00$ \\
\hline $\mathrm{K}$ & $\mathrm{mg} / \mathrm{L}$ & $1.35 \mathrm{E}+01$ & $1.85 \mathrm{E}+01$ & $1.90 \mathrm{E}+01$ & $1.54 \mathrm{E}+01$ & $1.72 \mathrm{E}+01$ \\
\hline $\mathrm{La}$ & $\mathrm{mg} / \mathrm{L}$ & 4.96E-01 & 4.53E-01 & $<3.28 E-01$ & $<3.11 E-01$ & $<3.49 E-01$ \\
\hline $\mathrm{Li}$ & $\mathrm{mg} / \mathrm{L}$ & $<3.24 E-01$ & $<3.33 E-01$ & $<3.28 E-01$ & $<3.11 E-01$ & $<3.49 E-01$ \\
\hline $\mathrm{Mg}$ & $\mathrm{mg} / \mathrm{L}$ & $8.81 \mathrm{E}+00$ & $8.61 \mathrm{E}+00$ & $8.64 \mathrm{E}+00$ & $8.13 \mathrm{E}+00$ & $<8.21 E-02$ \\
\hline $\mathrm{Mn}$ & $\mathrm{mg} / \mathrm{L}$ & $2.51 \mathrm{E}+02$ & $2.38 \mathrm{E}+02$ & $2.15 \mathrm{E}+00$ & 7.16E-01 & $2.03 \mathrm{E}+00$ \\
\hline $\mathrm{Na}$ & $\mathrm{mg} / \mathrm{L}$ & $3.56 \mathrm{E}+02$ & $3.57 \mathrm{E}+02$ & $3.58 \mathrm{E}+02$ & $3.52 \mathrm{E}+02$ & $3.36 \mathrm{E}+02$ \\
\hline $\mathrm{Ni}$ & $\mathrm{mg} / \mathrm{L}$ & $1.79 \mathrm{E}+01$ & $1.33 \mathrm{E}+01$ & $1.54 \mathrm{E}+01$ & $1.17 \mathrm{E}+01$ & $<2.34 E+00$ \\
\hline $\mathrm{P}$ & $\mathrm{mg} / \mathrm{L}$ & $<7.81 E+00$ & $<8.02 E+00$ & $<7.90 E+00$ & $<7.50 E+00$ & $<8.42 E+00$ \\
\hline S & $\mathrm{mg} / \mathrm{L}$ & $<3.57 E+01$ & $<3.67 E+01$ & $<3.61 E+01$ & $<3.43 E+01$ & $<3.85 E+01$ \\
\hline $\mathrm{Si}$ & $\mathrm{mg} / \mathrm{L}$ & $2.74 \mathrm{E}+01$ & $2.57 \mathrm{E}+01$ & $6.13 \mathrm{E}+00$ & $<4.47 E+00$ & $<5.02 E+00$ \\
\hline $\mathrm{Sr}$ & $\mathrm{mg} / \mathrm{L}$ & 7.40E-01 & 5.73E-01 & $6.51 \mathrm{E}-01$ & $<2.74 E-02$ & $<3.08 E-02$ \\
\hline Th & $\mathrm{mg} / \mathrm{L}$ & $3.61 \mathrm{E}+00$ & $3.71 \mathrm{E}+00$ & $<2.58 E+00$ & $<2.45 E+00$ & $<2.75 E+00$ \\
\hline $\mathrm{Ti}$ & $\mathrm{mg} / \mathrm{L}$ & 8.35E-01 & 8.32E-01 & 4.82E-01 & 4.14E-01 & 4.71E-01 \\
\hline $\mathrm{U}$ & $\mathrm{mg} / \mathrm{L}$ & $6.56 \mathrm{E}+01$ & $6.00 \mathrm{E}+01$ & $4.63 \mathrm{E}+01$ & $3.93 \mathrm{E}+01$ & $1.71 \mathrm{E}+01$ \\
\hline $\mathrm{Zn}$ & $\mathrm{mg} / \mathrm{L}$ & $1.28 \mathrm{E}+00$ & 8.40E-01 & 7.45E-01 & $<2.20 E-01$ & $<2.46 E-01$ \\
\hline $\mathrm{Zr}$ & $\mathrm{mg} / \mathrm{L}$ & $1.21 \mathrm{E}+01$ & $1.16 \mathrm{E}+01$ & $<2.70 E-01$ & $<2.56 E-01$ & $<2.87 E-01$ \\
\hline $\mathrm{Hg}$ & $\mathrm{mg} / \mathrm{L}$ & $<4.76 E-01$ & -- & - & -- & $<5.13 E-01$ \\
\hline Co & $\mathrm{mg} / \mathrm{L}$ & $1.76 \mathrm{E}-01$ & 1.11E-01 & 1.10E-01 & $<4.57 E-02$ & $<5.13 E-02$ \\
\hline $\mathrm{Pb}$ & $\mathrm{mg} / \mathrm{L}$ & 3.78E-01 & 2.88E-01 & $<2.17 E-01$ & $<2.06 E-01$ & $<2.32 E-01$ \\
\hline m-232 (Th) & $\mathrm{mg} / \mathrm{L}$ & $2.78 \mathrm{E}+00$ & $2.67 \mathrm{E}+00$ & $<7.23 E-02$ & $<6.86 E-02$ & $<7.70 E-02$ \\
\hline $\mathrm{m}-233(\mathrm{U})$ & $\mathrm{mg} / \mathrm{L}$ & $1.08 \mathrm{E}-01$ & $1.16 \mathrm{E}-01$ & $6.76 \mathrm{E}-02$ & 5.34E-02 & $<5.13 E-02$ \\
\hline $\mathrm{m}-234(\mathrm{U})$ & $\mathrm{mg} / \mathrm{L}$ & 7.25E-02 & $<7.34 E-02$ & $<7.23 E-02$ & $<6.86 E-02$ & $<7.70 E-02$ \\
\hline m-235 (U) & $\mathrm{mg} / \mathrm{L}$ & 9.82E-01 & 9.04E-01 & 7.40E-01 & 5.70E-01 & $6.97 \mathrm{E}-02$ \\
\hline m-236(U) & $\mathrm{mg} / \mathrm{L}$ & $1.11 \mathrm{E}-01$ & 1.03E-01 & 8.04E-02 & $6.82 \mathrm{E}-02$ & $<5.13 E-02$ \\
\hline m-237 (Np) & $\mathrm{mg} / \mathrm{L}$ & $<9.53 E-02$ & $<9.79 E-02$ & $<9.64 E-02$ & $<9.15 E-02$ & $<1.03 E-01$ \\
\hline m-238 (U,Pu) & $\mathrm{mg} / \mathrm{L}$ & $6.61 \mathrm{E}+01$ & $6.17 \mathrm{E}+01$ & $4.80 \mathrm{E}+01$ & $3.77 \mathrm{E}+01$ & $3.11 \mathrm{E}+00$ \\
\hline m-239 (Pu) & $\mathrm{mg} / \mathrm{L}$ & 3.85E-01 & 3.87E-01 & $<9.64 E-02$ & $<9.15 E-02$ & $<1.03 E-01$ \\
\hline $\mathrm{m}-240(\mathrm{Pu})$ & $\mathrm{mg} / \mathrm{L}$ & 5.77E-02 & 7.13E-02 & $<4.82 E-02$ & $<4.57 E-02$ & $<5.13 E-02$ \\
\hline $\mathrm{Pu}-238$ & $\mathrm{dpm} / \mathrm{mL}$ & $1.31 \mathrm{E}+06$ & $1.17 \mathrm{E}+06$ & $1.60 \mathrm{E}+05$ & $1.56 \mathrm{E}+05$ & $2.03 \mathrm{E}+04$ \\
\hline $\mathrm{Pu}-239 / 240$ & $\mathrm{dpm} / \mathrm{mL}$ & $8.05 \mathrm{E}+04$ & $6.44 \mathrm{E}+04$ & $8.91 \mathrm{E}+03$ & $9.52 \mathrm{E}+03$ & $1.45 \mathrm{E}+03$ \\
\hline Sr-90 & $\mathrm{dpm} / \mathrm{mL}$ & $1.61 \mathrm{E}+08$ & - & - & -- & $1.03 \mathrm{E}+06$ \\
\hline Cs -137 & $\mathrm{dpm} / \mathrm{mL}$ & $2.27 \mathrm{E}+06$ & -- & - & -- & $2.12 \mathrm{E}+06$ \\
\hline
\end{tabular}


Table 3-2: Soluble Components throughout ECC Oxalate Decomposition: Test 3 (Tank 12H) OA Batch 2

\begin{tabular}{|c|c|c|c|c|c|c|}
\hline analyte & units & initial & 1st sample & 2nd sample & 3rd sample & final sample \\
\hline time & $\mathrm{hr}$ & 0.0 & 1.3 & 3.4 & 4.4 & 6.4 \\
\hline $\mathrm{pH}$ & -- & 1.13 & 2.73 & 4.16 & 6.42 & 6.26 \\
\hline ORP & $\mathrm{mV}$ & 547 & 660 & 771 & 864 & 973 \\
\hline Oxalate & $\mathrm{mg} / \mathrm{L}$ & $8.54 \mathrm{E}+03$ & $2.70 \mathrm{E}+03$ & $3.58 \mathrm{E}+02$ & $<8.95 E+01$ & $<1.00 E+02$ \\
\hline Ag & $\mathrm{mg} / \mathrm{L}$ & $<6.93 E-01$ & $<7.17 E-01$ & $<6.88 E-01$ & $<6.54 E-01$ & $<7.31 E-01$ \\
\hline $\mathrm{Al}$ & $\mathrm{mg} / \mathrm{L}$ & $5.27 \mathrm{E}+02$ & $5.15 \mathrm{E}+02$ & $5.00 \mathrm{E}+01$ & $<1.49 E+00$ & $<1.66 E+00$ \\
\hline B & $\mathrm{mg} / \mathrm{L}$ & $<9.58 E-01$ & $<9.92 E-01$ & $<9.52 E-01$ & $<9.04 E-01$ & $<1.01 E+00$ \\
\hline $\mathrm{Ba}$ & $\mathrm{mg} / \mathrm{L}$ & $<2.85 E-02$ & $<2.95 E-02$ & $<2.83 E-02$ & $<2.69 E-02$ & $<3.01 E-02$ \\
\hline $\mathrm{Ca}$ & $\mathrm{mg} / \mathrm{L}$ & $3.00 \mathrm{E}+00$ & $2.57 \mathrm{E}+00$ & $2.69 \mathrm{E}+00$ & $1.25 \mathrm{E}+00$ & $1.92 \mathrm{E}+00$ \\
\hline Cd & $\mathrm{mg} / \mathrm{L}$ & $<1.52 E-01$ & $<1.57 E-01$ & $<1.51 E-01$ & $<1.43 E-01$ & $<1.60 E-01$ \\
\hline $\mathrm{Ce}$ & $\mathrm{mg} / \mathrm{L}$ & $<3.36 E+00$ & $<3.48 E+00$ & $<3.34 E+00$ & $<3.17 E+00$ & $<3.55 E+00$ \\
\hline $\mathrm{Cr}$ & $\mathrm{mg} / \mathrm{L}$ & $1.02 \mathrm{E}+00$ & $6.80 \mathrm{E}-01$ & $<3.86 E-01$ & $<3.67 E-01$ & $<4.11 E-01$ \\
\hline $\mathrm{Cu}$ & $\mathrm{mg} / \mathrm{L}$ & $1.14 \mathrm{E}+00$ & $1.20 \mathrm{E}+00$ & $6.90 \mathrm{E}-01$ & $<2.87 E-01$ & 3.46E-01 \\
\hline $\mathrm{Fe}$ & $\mathrm{mg} / \mathrm{L}$ & $1.37 \mathrm{E}+02$ & $1.31 \mathrm{E}+02$ & $5.00 \mathrm{E}+00$ & $<4.30 E-01$ & $6.47 \mathrm{E}-01$ \\
\hline Gd & $\mathrm{mg} / \mathrm{L}$ & $<1.02 E+00$ & $<1.06 E+00$ & $<1.02 E+00$ & $<9.67 E-01$ & $<1.08 E+00$ \\
\hline $\mathrm{K}$ & $\mathrm{mg} / \mathrm{L}$ & $1.58 \mathrm{E}+01$ & $1.76 \mathrm{E}+01$ & $1.45 \mathrm{E}+01$ & $1.45 \mathrm{E}+01$ & $1.52 \mathrm{E}+01$ \\
\hline $\mathrm{La}$ & $\mathrm{mg} / \mathrm{L}$ & $<3.23 E-01$ & $<3.34 E-01$ & $<3.20 E-01$ & $<3.04 E-01$ & $<3.41 E-01$ \\
\hline $\mathrm{Li}$ & $\mathrm{mg} / \mathrm{L}$ & $<3.23 E-01$ & $<3.34 E-01$ & $<3.20 E-01$ & $<3.04 E-01$ & $<3.41 E-01$ \\
\hline $\mathrm{Mg}$ & $\mathrm{mg} / \mathrm{L}$ & 5.83E-01 & $5.22 \mathrm{E}-01$ & 6.96E-01 & 2.25E-01 & 2.21E-01 \\
\hline Mn & $\mathrm{mg} / \mathrm{L}$ & $4.38 \mathrm{E}+01$ & 4.23E+01 & $1.71 \mathrm{E}+00$ & $<2.42 E-01$ & $<2.71 E-01$ \\
\hline $\mathrm{Na}$ & $\mathrm{mg} / \mathrm{L}$ & $<3.50 E+01$ & $<3.62 E+01$ & $<3.48 E+01$ & $<3.30 E+01$ & $<3.70 E+01$ \\
\hline $\mathrm{Ni}$ & $\mathrm{mg} / \mathrm{L}$ & $3.79 \mathrm{E}+00$ & $3.76 \mathrm{E}+00$ & $4.86 \mathrm{E}+00$ & $<2.04 E+00$ & $<2.28 E+00$ \\
\hline $\mathrm{P}$ & $\mathrm{mg} / \mathrm{L}$ & $<7.78 E+00$ & $<8.05 E+00$ & $<7.73 E+00$ & $<7.34 E+00$ & $<8.22 E+00$ \\
\hline S & $\mathrm{mg} / \mathrm{L}$ & $<3.56 E+01$ & $<3.68 E+01$ & $<3.53 E+01$ & $<3.36 E+01$ & $<3.76 E+01$ \\
\hline $\mathrm{Si}$ & $\mathrm{mg} / \mathrm{L}$ & $<4.64 E+00$ & $<4.80 E+00$ & $<4.61 E+00$ & $<4.38 E+00$ & $<4.90 E+00$ \\
\hline $\mathrm{Sr}$ & $\mathrm{mg} / \mathrm{L}$ & $<2.85 E-02$ & $<2.95 E-02$ & $<2.83 E-02$ & $<2.69 E-02$ & $<3.01 E-02$ \\
\hline Th & $\mathrm{mg} / \mathrm{L}$ & $7.23 \mathrm{E}+00$ & $3.21 \mathrm{E}+00$ & $<2.53 E+00$ & $<2.40 E+00$ & $<2.69 E+00$ \\
\hline $\mathrm{Ti}$ & $\mathrm{mg} / \mathrm{L}$ & 9.49E-01 & 4.89E-01 & 4.02E-01 & $4.21 \mathrm{E}-01$ & 4.31E-01 \\
\hline $\mathrm{U}$ & $\mathrm{mg} / \mathrm{L}$ & $2.09 \mathrm{E}+01$ & $1.89 \mathrm{E}+01$ & $<1.54 E+01$ & $<1.46 E+01$ & $<1.63 E+01$ \\
\hline $\mathrm{Zn}$ & $\mathrm{mg} / \mathrm{L}$ & $<2.28 E-01$ & $<2.36 E-01$ & $<2.26 E-01$ & $<2.15 E-01$ & $<2.40 E-01$ \\
\hline $\mathrm{Zr}$ & $\mathrm{mg} / \mathrm{L}$ & $3.41 \mathrm{E}+00$ & $1.48 \mathrm{E}+00$ & $<2.64 E-01$ & $<2.51 E-01$ & $<2.81 E-01$ \\
\hline $\mathrm{Hg}$ & $\mathrm{mg} / \mathrm{L}$ & $<4.74 E-01$ & -- & -- & -- & $<5.01 E-01$ \\
\hline Co & $\mathrm{mg} / \mathrm{L}$ & $8.16 \mathrm{E}-02$ & $<4.91 E-02$ & $<4.71 E-02$ & $<4.48 E-02$ & $<5.01 E-02$ \\
\hline $\mathrm{Pb}$ & $\mathrm{mg} / \mathrm{L}$ & $<2.46 E-01$ & $<2.21 E-01$ & $<2.12 E-01$ & $<2.08 E-01$ & $<2.30 E-01$ \\
\hline m-232 (Th) & $\mathrm{mg} / \mathrm{L}$ & $6.83 \mathrm{E}+00$ & $3.27 \mathrm{E}+00$ & 7.36E-02 & $<6.72 E-02$ & $<7.51 E-02$ \\
\hline $\mathrm{m}-233(\mathrm{U})$ & $\mathrm{mg} / \mathrm{L}$ & $<4.74 E-02$ & $<4.91 E-02$ & $<4.71 E-02$ & $<4.48 E-02$ & $<5.01 E-02$ \\
\hline $\mathrm{m}-234(\mathrm{U})$ & $\mathrm{mg} / \mathrm{L}$ & $<7.12 E-02$ & $<7.36 E-02$ & $<7.07 E-02$ & $<6.72 E-02$ & $<7.51 E-02$ \\
\hline m-235(U) & $\mathrm{mg} / \mathrm{L}$ & 1.62E-01 & $1.26 \mathrm{E}-01$ & 1.05E-01 & $<4.48 E-02$ & $<5.01 E-02$ \\
\hline m-236(U) & $\mathrm{mg} / \mathrm{L}$ & $<4.74 E-02$ & $<4.91 E-02$ & $<4.71 E-02$ & $<4.48 E-02$ & $<5.01 E-02$ \\
\hline m-237 (Np) & $\mathrm{mg} / \mathrm{L}$ & $<9.49 E-02$ & $<9.82 E-02$ & $<9.43 E-02$ & $<8.95 E-02$ & $<1.00 E-01$ \\
\hline m-238 (U,Pu) & $\mathrm{mg} / \mathrm{L}$ & $8.34 \mathrm{E}+00$ & $7.37 \mathrm{E}+00$ & $4.34 \mathrm{E}+00$ & $<4.48 E-02$ & $<5.01 E-02$ \\
\hline $\mathrm{m}-239(\mathrm{Pu})$ & $\mathrm{mg} / \mathrm{L}$ & $1.85 \mathrm{E}-01$ & $1.16 \mathrm{E}-01$ & $<9.43 E-02$ & $<8.95 E-02$ & $<1.00 E-01$ \\
\hline $\mathrm{m}-240(\mathrm{Pu})$ & $\mathrm{mg} / \mathrm{L}$ & $<4.74 E-02$ & $<4.91 E-02$ & $<4.71 E-02$ & $<4.48 E-02$ & $<5.01 E-02$ \\
\hline $\mathrm{Pu}-238$ & $\mathrm{dpm} / \mathrm{mL}$ & $5.72 \mathrm{E}+05$ & $2.86 \mathrm{E}+05$ & $8.30 \mathrm{E}+04$ & $<7.38 E+02$ & $1.76 \mathrm{E}+04$ \\
\hline $\mathrm{Pu}-239 / 240$ & $\mathrm{dpm} / \mathrm{mL}$ & $2.73 \mathrm{E}+04$ & $1.15 \mathrm{E}+04$ & $5.53 \mathrm{E}+03$ & $<7.61 E+02$ & $<1.37 E+03$ \\
\hline Sr-90 & $\mathrm{dpm} / \mathrm{mL}$ & $2.75 \mathrm{E}+07$ & -- & - & -- & $1.97 \mathrm{E}+07$ \\
\hline Cs-137 & $\mathrm{dpm} / \mathrm{mL}$ & $1.99 \mathrm{E}+05$ & - & -- & -- & $2.23 \mathrm{E}+05$ \\
\hline
\end{tabular}


Table 3-3: Soluble Components throughout ECC Oxalate Decomposition: Test 4 (Tank 5F) OA Batch 1

\begin{tabular}{|c|c|c|c|c|c|c|}
\hline analyte & units & initial & 1st sample & 2nd sample & 3rd sample & final sample \\
\hline time & $\mathrm{hr}$ & 0.0 & 0.7 & 1.4 & 2.1 & 5.5 \\
\hline $\mathrm{pH}$ & -- & 1.35 & 2.48 & 4.14 & 6.09 & 8.53 \\
\hline ORP & $\mathrm{mV}$ & 217 & 326 & 696 & 788 & 746 \\
\hline Oxalate & $\mathrm{mg} / \mathrm{L}$ & $1.40 \mathrm{E}+04$ & $4.53 \mathrm{E}+03$ & $2.80 \mathrm{E}+03$ & $1.99 \mathrm{E}+03$ & $1.12 \mathrm{E}+02$ \\
\hline Ag & $\mathrm{mg} / \mathrm{L}$ & $<7.16 E+00$ & $<6.65 E+00$ & $<6.79 E+00$ & $<7.21 E+00$ & $<7.03 E+00$ \\
\hline $\mathrm{Al}$ & $\mathrm{mg} / \mathrm{L}$ & $3.03 \mathrm{E}+02$ & $3.10 \mathrm{E}+02$ & $2.86 \mathrm{E}+02$ & $1.57 \mathrm{E}+02$ & $3.36 \mathrm{E}+01$ \\
\hline B & $\mathrm{mg} / \mathrm{L}$ & $3.70 \mathrm{E}+00$ & $2.66 \mathrm{E}+00$ & $<6.70 E-01$ & $<7.11 E-01$ & $<6.94 E-01$ \\
\hline $\mathrm{Ba}$ & $\mathrm{mg} / \mathrm{L}$ & $2.18 \mathrm{E}+01$ & $1.84 \mathrm{E}+01$ & $6.04 \mathrm{E}+00$ & 8.06E-01 & 5.79E-01 \\
\hline $\mathrm{Ca}$ & $\mathrm{mg} / \mathrm{L}$ & $5.00 \mathrm{E}+01$ & $4.80 \mathrm{E}+01$ & $3.95 \mathrm{E}+01$ & $1.33 \mathrm{E}+01$ & $9.57 \mathrm{E}+00$ \\
\hline $\mathrm{Cd}$ & $\mathrm{mg} / \mathrm{L}$ & $<3.18 E-01$ & $<2.96 E-01$ & $<3.02 E-01$ & $<3.20 E-01$ & $<3.13 E-01$ \\
\hline Ce & $\mathrm{mg} / \mathrm{L}$ & $<3.52 E+00$ & $<3.27 E+00$ & $<3.34 E+00$ & $<3.54 E+00$ & $<3.46 E+00$ \\
\hline $\mathrm{Cr}$ & $\mathrm{mg} / \mathrm{L}$ & $8.31 \mathrm{E}+00$ & $8.58 \mathrm{E}+00$ & $8.13 \mathrm{E}+00$ & $7.57 \mathrm{E}+00$ & $6.25 \mathrm{E}+00$ \\
\hline $\mathrm{Cu}$ & $\mathrm{mg} / \mathrm{L}$ & $<3.18 E-01$ & $<2.96 E-01$ & $<3.02 E-01$ & $<3.20 E-01$ & $<3.13 E-01$ \\
\hline $\mathrm{Fe}$ & $\mathrm{mg} / \mathrm{L}$ & $1.02 \mathrm{E}+03$ & $7.66 \mathrm{E}+02$ & $1.07 \mathrm{E}+02$ & $1.45 \mathrm{E}+01$ & $3.40 \mathrm{E}+00$ \\
\hline Gd & $\mathrm{mg} / \mathrm{L}$ & $3.34 \mathrm{E}+00$ & $2.78 \mathrm{E}+00$ & $3.27 \mathrm{E}+00$ & $2.95 \mathrm{E}+00$ & $1.80 \mathrm{E}+00$ \\
\hline $\mathrm{K}$ & $\mathrm{mg} / \mathrm{L}$ & $1.74 \mathrm{E}+01$ & $1.64 \mathrm{E}+01$ & $1.70 \mathrm{E}+01$ & $1.52 \mathrm{E}+01$ & $<1.32 E+01$ \\
\hline $\mathrm{La}$ & $\mathrm{mg} / \mathrm{L}$ & $<3.33 E+00$ & $<3.10 E+00$ & $<3.16 E+00$ & $<3.35 E+00$ & $<3.27 E+00$ \\
\hline $\mathrm{Li}$ & $\mathrm{mg} / \mathrm{L}$ & $6.04 \mathrm{E}+00$ & $5.93 \mathrm{E}+00$ & $5.92 \mathrm{E}+00$ & $5.88 \mathrm{E}+00$ & $2.36 \mathrm{E}+00$ \\
\hline $\mathrm{Mg}$ & $\mathrm{mg} / \mathrm{L}$ & $5.02 \mathrm{E}+00$ & $4.27 \mathrm{E}+00$ & $4.67 \mathrm{E}+00$ & $4.44 \mathrm{E}+00$ & 3.35E-01 \\
\hline Mn & $\mathrm{mg} / \mathrm{L}$ & $2.82 E+02$ & $2.44 \mathrm{E}+02$ & $3.79 \mathrm{E}+01$ & $3.68 \mathrm{E}-01$ & $1.89 \mathrm{E}+00$ \\
\hline $\mathrm{Na}$ & $\mathrm{mg} / \mathrm{L}$ & $5.98 \mathrm{E}+02$ & $5.75 \mathrm{E}+02$ & $5.75 \mathrm{E}+02$ & $5.62 \mathrm{E}+02$ & $5.42 \mathrm{E}+02$ \\
\hline $\mathrm{Ni}$ & $\mathrm{mg} / \mathrm{L}$ & $<2.27 E+00$ & $<2.11 E+00$ & $<2.15 E+00$ & $<2.28 E+00$ & $<2.23 E+00$ \\
\hline $\mathrm{P}$ & $\mathrm{mg} / \mathrm{L}$ & $<8.15 E+00$ & $<7.58 E+00$ & $<7.74 E+00$ & $<8.21 E+00$ & $<8.01 E+00$ \\
\hline S & $\mathrm{mg} / \mathrm{L}$ & $<3.73 E+01$ & $<3.47 E+01$ & $<3.54 E+01$ & $<3.75 E+01$ & $<3.66 E+01$ \\
\hline $\mathrm{Si}$ & $\mathrm{mg} / \mathrm{L}$ & $9.48 \mathrm{E}+01$ & $9.80 \mathrm{E}+01$ & $8.05 \mathrm{E}+01$ & $3.80 \mathrm{E}+01$ & $7.01 \mathrm{E}+00$ \\
\hline $\mathrm{Sr}$ & $\mathrm{mg} / \mathrm{L}$ & $1.03 \mathrm{E}+01$ & $9.07 \mathrm{E}+00$ & $6.90 \mathrm{E}+00$ & $2.97 \mathrm{E}+00$ & $1.35 \mathrm{E}+00$ \\
\hline Th & $\mathrm{mg} / \mathrm{L}$ & $<2.66 E+00$ & $<2.48 E+00$ & $<2.53 E+00$ & $<2.68 E+00$ & $<2.62 E+00$ \\
\hline $\mathrm{Ti}$ & $\mathrm{mg} / \mathrm{L}$ & 9.30E-01 & 9.52E-01 & $<1.79 E-01$ & $<1.90 E-01$ & $<1.86 E-01$ \\
\hline $\mathrm{U}$ & $\mathrm{mg} / \mathrm{L}$ & $1.31 \mathrm{E}+03$ & $1.14 \mathrm{E}+03$ & $1.17 \mathrm{E}+03$ & $1.04 \mathrm{E}+03$ & $6.47 \mathrm{E}+02$ \\
\hline $\mathrm{Zn}$ & $\mathrm{mg} / \mathrm{L}$ & $<3.28 E-01$ & $<3.05 E-01$ & $<3.11 E-01$ & $<3.30 E-01$ & $<3.22 E-01$ \\
\hline $\mathrm{Zr}$ & $\mathrm{mg} / \mathrm{L}$ & $5.28 \mathrm{E}+01$ & $5.32 \mathrm{E}+01$ & $1.63 \mathrm{E}+00$ & $<2.80 E-01$ & $<2.74 E-01$ \\
\hline $\mathrm{Hg}$ & $\mathrm{mg} / \mathrm{L}$ & $<4.97 E-01$ & - & -- & -- & $<4.88 E-01$ \\
\hline Co & $\mathrm{mg} / \mathrm{L}$ & $<1.49 E+00$ & $<1.39 E+00$ & $<1.42 E+00$ & $<1.50 E+00$ & $<1.47 E+00$ \\
\hline $\mathrm{Pb}$ & $\mathrm{mg} / \mathrm{L}$ & $<6.96 E+00$ & $<6.47 E+00$ & $<6.61 E+00$ & $5.32 \mathrm{E}+01$ & $<6.84 E+00$ \\
\hline $\mathrm{m}-232(\mathrm{Th})$ & $\mathrm{mg} / \mathrm{L}$ & $<1.49 E+00$ & $<1.39 E+00$ & $<1.42 E+00$ & $<1.50 E+00$ & $<1.47 E+00$ \\
\hline m-233 (U) & $\mathrm{mg} / \mathrm{L}$ & $<9.94 E-01$ & $<9.24 E-01$ & $<9.44 E-01$ & $<1.00 E+00$ & $<9.77 E-01$ \\
\hline m-234(U) & $\mathrm{mg} / \mathrm{L}$ & $<9.94 E-01$ & $<9.24 E-01$ & $<9.44 E-01$ & $<1.00 E+00$ & $<9.77 E-01$ \\
\hline $\mathrm{m}-235(\mathrm{U})$ & $\mathrm{mg} / \mathrm{L}$ & $9.28 \mathrm{E}+00$ & $6.98 \mathrm{E}+00$ & $7.19 \mathrm{E}+00$ & $6.83 \mathrm{E}+00$ & $4.41 \mathrm{E}+00$ \\
\hline m-236 (U) & $\mathrm{mg} / \mathrm{L}$ & $<9.94 E-01$ & $<9.24 E-01$ & $<9.44 E-01$ & $<1.00 E+00$ & $<9.77 E-01$ \\
\hline m-237 (Np) & $\mathrm{mg} / \mathrm{L}$ & $<9.94 E-01$ & $<9.24 E-01$ & $<9.44 E-01$ & $<1.00 E+00$ & $<9.77 E-01$ \\
\hline m-238 (U,Pu) & $\mathrm{mg} / \mathrm{L}$ & $1.29 \mathrm{E}+03$ & $1.08 \mathrm{E}+03$ & $1.18 \mathrm{E}+03$ & $1.04 \mathrm{E}+03$ & $6.31 \mathrm{E}+02$ \\
\hline $\mathrm{m}-239(\mathrm{Pu})$ & $\mathrm{mg} / \mathrm{L}$ & $<9.94 E-01$ & $<9.24 E-01$ & $<9.44 E-01$ & $<1.00 E+00$ & $<9.77 E-01$ \\
\hline $\mathrm{m}-240(\mathrm{Pu})$ & $\mathrm{mg} / \mathrm{L}$ & $<9.94 E-01$ & $<9.24 E-01$ & $<9.44 E-01$ & $<1.00 E+00$ & $<9.77 E-01$ \\
\hline $\mathrm{Pu}-238$ & $\mathrm{dpm} / \mathrm{mL}$ & $1.34 \mathrm{E}+05$ & $4.22 \mathrm{E}+04$ & $8.33 \mathrm{E}+03$ & $8.87 \mathrm{E}+03$ & $5.24 \mathrm{E}+03$ \\
\hline Pu-239/240 & $\mathrm{dpm} / \mathrm{mL}$ & $3.17 \mathrm{E}+04$ & $1.84 \mathrm{E}+04$ & $3.22 \mathrm{E}+03$ & $4.25 \mathrm{E}+03$ & $3.01 \mathrm{E}+03$ \\
\hline Sr-90 & $\mathrm{dpm} / \mathrm{mL}$ & $8.51 E+08$ & -- & -- & -- & $1.02 \mathrm{E}+08$ \\
\hline Cs-137 & $\mathrm{dpm} / \mathrm{mL}$ & $3.81 \mathrm{E}+07$ & -- & -- & -- & $3.69 \mathrm{E}+07$ \\
\hline
\end{tabular}


Table 3-4: Soluble Components throughout ECC Oxalate Decomposition: Test 4 (Tank 5F) OA Batch 2

\begin{tabular}{|c|c|c|c|c|c|c|}
\hline analyte & units & initial & 1st sample & 2nd sample & 3rd sample & final sample \\
\hline time & $\mathrm{hr}$ & 0.0 & 1.2 & 1.6 & 2.0 & 4.5 \\
\hline $\mathrm{pH}$ & -- & 1.11 & 3.13 & 4.85 & 6.69 & 8.41 \\
\hline ORP & $\mathrm{mV}$ & 219 & 327 & 845 & 848 & 828 \\
\hline Oxalate & $\mathrm{mg} / \mathrm{L}$ & $1.00 \mathrm{E}+04$ & $4.70 \mathrm{E}+02$ & $1.96 \mathrm{E}+02$ & $<9.45 E+01$ & $<9.56 E+01$ \\
\hline Ag & $\mathrm{mg} / \mathrm{L}$ & $<6.81 E+00$ & $<6.91 E+00$ & $<7.04 E+00$ & $<6.80 E+00$ & $<6.89 E+00$ \\
\hline $\mathrm{Al}$ & $\mathrm{mg} / \mathrm{L}$ & $3.11 \mathrm{E}+01$ & $1.75 \mathrm{E}+01$ & $1.65 \mathrm{E}+01$ & $3.24 \mathrm{E}+00$ & $4.92 \mathrm{E}+00$ \\
\hline B & $\mathrm{mg} / \mathrm{L}$ & $<6.71 E-01$ & $<6.82 E-01$ & $<6.94 E-01$ & $<6.71 E-01$ & $<6.79 E-01$ \\
\hline $\mathrm{Ba}$ & $\mathrm{mg} / \mathrm{L}$ & $2.92 \mathrm{E}+00$ & $1.88 \mathrm{E}+00$ & 8.21E-01 & 1.13E-01 & 7.59E-02 \\
\hline $\mathrm{Ca}$ & $\mathrm{mg} / \mathrm{L}$ & $6.35 \mathrm{E}+00$ & $4.41 \mathrm{E}+00$ & $4.24 \mathrm{E}+00$ & $2.62 \mathrm{E}+00$ & $1.28 \mathrm{E}+00$ \\
\hline $\mathrm{Cd}$ & $\mathrm{mg} / \mathrm{L}$ & $<3.03 E-01$ & $<3.07 E-01$ & $<3.13 E-01$ & $<3.02 E-01$ & $<3.06 E-01$ \\
\hline Ce & $\mathrm{mg} / \mathrm{L}$ & $<3.35 E+00$ & $<3.40 E+00$ & $<3.46 E+00$ & $<3.34 E+00$ & $<3.39 E+00$ \\
\hline $\mathrm{Cr}$ & $\mathrm{mg} / \mathrm{L}$ & $1.21 \mathrm{E}+00$ & 6.34E-01 & 8.46E-01 & 5.57E-01 & $<1.02 E+00$ \\
\hline $\mathrm{Cu}$ & $\mathrm{mg} / \mathrm{L}$ & $<3.03 E-01$ & $<3.07 E-01$ & $<3.13 E-01$ & $<3.02 E-01$ & $<3.06 E-01$ \\
\hline $\mathrm{Fe}$ & $\mathrm{mg} / \mathrm{L}$ & $6.69 \mathrm{E}+01$ & $6.13 \mathrm{E}+01$ & $5.46 \mathrm{E}+00$ & $1.62 \mathrm{E}+00$ & $2.72 \mathrm{E}+00$ \\
\hline Gd & $\mathrm{mg} / \mathrm{L}$ & $<1.02 E+00$ & $<1.04 E+00$ & $<1.06 E+00$ & $<1.02 E+00$ & $<1.03 E+00$ \\
\hline $\mathrm{K}$ & $\mathrm{mg} / \mathrm{L}$ & $<1.21 E+01$ & $<1.23 E+01$ & $<1.25 E+01$ & $<1.21 E+01$ & $<1.22 E+01$ \\
\hline $\mathrm{La}$ & $\mathrm{mg} / \mathrm{L}$ & $<3.17 E+00$ & $<3.22 E+00$ & $<3.27 E+00$ & $<3.16 E+00$ & $<3.20 E+00$ \\
\hline $\mathrm{Li}$ & $\mathrm{mg} / \mathrm{L}$ & $1.26 \mathrm{E}+00$ & 7.68E-01 & $1.03 \mathrm{E}+00$ & 8.69E-01 & $<1.00 E+00$ \\
\hline $\mathrm{Mg}$ & $\mathrm{mg} / \mathrm{L}$ & 8.02E-01 & 5.07E-01 & $6.04 \mathrm{E}-01$ & 3.76E-01 & $1.48 \mathrm{E}-01$ \\
\hline $\mathrm{Mn}$ & $\mathrm{mg} / \mathrm{L}$ & $1.97 \mathrm{E}+01$ & $1.37 \mathrm{E}+01$ & $1.91 \mathrm{E}+00$ & $<2.55 E-01$ & $<4.96 E-01$ \\
\hline $\mathrm{Na}$ & $\mathrm{mg} / \mathrm{L}$ & $6.12 \mathrm{E}+01$ & $3.61 \mathrm{E}+01$ & $4.09 \mathrm{E}+01$ & $<3.49 E+01$ & $<4.87 E+01$ \\
\hline $\mathrm{Ni}$ & $\mathrm{mg} / \mathrm{L}$ & $<2.16 E+00$ & $<2.19 E+00$ & $<2.23 E+00$ & $<2.15 E+00$ & $<2.18 E+00$ \\
\hline $\mathrm{P}$ & $\mathrm{mg} / \mathrm{L}$ & $<7.75 E+00$ & $<7.87 E+00$ & $<8.02 E+00$ & $<7.75 E+00$ & $<7.84 E+00$ \\
\hline S & $\mathrm{mg} / \mathrm{L}$ & $<3.55 E+01$ & $<3.60 E+01$ & $<3.67 E+01$ & $<3.54 E+01$ & $<3.59 E+01$ \\
\hline $\mathrm{Si}$ & $\mathrm{mg} / \mathrm{L}$ & $1.72 \mathrm{E}+01$ & $1.09 \mathrm{E}+01$ & $1.11 \mathrm{E}+01$ & $4.42 \mathrm{E}+00$ & $2.86 \mathrm{E}+00$ \\
\hline $\mathrm{Sr}$ & $\mathrm{mg} / \mathrm{L}$ & $1.21 \mathrm{E}+00$ & 7.06E-01 & 6.16E-01 & $2.41 \mathrm{E}-01$ & 4.26E-02 \\
\hline Th & $\mathrm{mg} / \mathrm{L}$ & $<2.53 E+00$ & $<2.57 E+00$ & $<2.62 E+00$ & $<2.53 E+00$ & $<2.56 E+00$ \\
\hline $\mathrm{Ti}$ & $\mathrm{mg} / \mathrm{L}$ & $<1.80 E-01$ & $<1.82 E-01$ & $<1.86 E-01$ & $<1.79 E-01$ & $<1.82 E-01$ \\
\hline $\mathrm{U}$ & $\mathrm{mg} / \mathrm{L}$ & $8.00 \mathrm{E}+01$ & $4.24 \mathrm{E}+01$ & $5.02 \mathrm{E}+01$ & $2.23 \mathrm{E}+01$ & $<1.56 E+01$ \\
\hline $\mathrm{Zn}$ & $\mathrm{mg} / \mathrm{L}$ & $<3.12 E-01$ & $<3.17 E-01$ & $<3.23 E-01$ & $<3.12 E-01$ & $<3.16 E-01$ \\
\hline $\mathrm{Zr}$ & $\mathrm{mg} / \mathrm{L}$ & $4.91 \mathrm{E}+00$ & $2.87 \mathrm{E}+00$ & $<2.74 E-01$ & $<2.64 E-01$ & $<2.68 E-01$ \\
\hline $\mathrm{Hg}$ & $\mathrm{mg} / \mathrm{L}$ & $<4.73 E-01$ & -- & -- & -- & $<4.78 E-01$ \\
\hline Co & $\mathrm{mg} / \mathrm{L}$ & $<1.42 E-01$ & $<1.44 E-01$ & $<1.47 E-01$ & $<7.08 E-02$ & $<7.17 E-02$ \\
\hline $\mathrm{Pb}$ & $\mathrm{mg} / \mathrm{L}$ & $1.42 \mathrm{E}+03$ & $<6.72 E-01$ & $<6.84 E-01$ & $4.22 \mathrm{E}+00$ & $<3.35 E-01$ \\
\hline $\mathrm{m}-232(\mathrm{Th})$ & $\mathrm{mg} / \mathrm{L}$ & 5.87E-01 & 4.44E-01 & $<1.47 E-01$ & $<7.08 E-02$ & $<7.17 E-02$ \\
\hline $\mathrm{m}-233(\mathrm{U})$ & $\mathrm{mg} / \mathrm{L}$ & $<9.46 E-02$ & $<9.60 E-02$ & $<9.78 E-02$ & $<4.72 E-02$ & $<4.78 E-02$ \\
\hline $\mathrm{m}-234(\mathrm{U})$ & $\mathrm{mg} / \mathrm{L}$ & $<9.46 E-02$ & $<9.60 E-02$ & $<9.78 E-02$ & $<4.72 E-02$ & $<4.78 E-02$ \\
\hline $\mathrm{m}-235(\mathrm{U})$ & $\mathrm{mg} / \mathrm{L}$ & 5.79E-01 & 3.08E-01 & 3.29E-01 & 1.47E-01 & $<5.50 E-02$ \\
\hline m-236(U) & $\mathrm{mg} / \mathrm{L}$ & $<9.46 E-02$ & $<9.60 E-02$ & $<9.78 E-02$ & $<4.72 E-02$ & $<4.78 E-02$ \\
\hline m-237 (Np) & $\mathrm{mg} / \mathrm{L}$ & $<9.46 E-02$ & $<9.60 E-02$ & $<9.78 E-02$ & $<4.72 E-02$ & $<4.78 E-02$ \\
\hline m-238 (U,Pu) & $\mathrm{mg} / \mathrm{L}$ & $8.59 \mathrm{E}+01$ & $4.14 \mathrm{E}+01$ & $4.61 \mathrm{E}+01$ & $1.85 \mathrm{E}+01$ & $3.47 \mathrm{E}+00$ \\
\hline m-239 (Pu) & $\mathrm{mg} / \mathrm{L}$ & $<9.46 E-02$ & $<9.60 E-02$ & $<9.78 E-02$ & $<4.72 E-02$ & $<4.78 E-02$ \\
\hline $\mathrm{m}-240(\mathrm{Pu})$ & $\mathrm{mg} / \mathrm{L}$ & $<9.46 E-02$ & $<9.60 E-02$ & $<9.78 E-02$ & $<4.72 E-02$ & $<4.78 E-02$ \\
\hline Pu-238 & $\mathrm{dpm} / \mathrm{mL}$ & $3.60 \mathrm{E}+04$ & $3.44 \mathrm{E}+04$ & $5.61 \mathrm{E}+03$ & $7.55 E+03$ & $<1.43 E+03$ \\
\hline Pu-239/240 & $\mathrm{dpm} / \mathrm{mL}$ & $1.13 \mathrm{E}+04$ & $9.31 \mathrm{E}+03$ & $1.60 \mathrm{E}+03$ & $2.83 \mathrm{E}+03$ & $<1.05 E+03$ \\
\hline Sr-90 & $\mathrm{dpm} / \mathrm{mL}$ & $1.62 \mathrm{E}+08$ & - & - & -- & $3.41 \mathrm{E}+06$ \\
\hline Cs-137 & $\mathrm{dpm} / \mathrm{mL}$ & $4.87 \mathrm{E}+06$ & -- & -- & -- & $2.77 \mathrm{E}+06$ \\
\hline
\end{tabular}


Table 3-5: Decomposition Module Feed and Product Slurry Analysis

\begin{tabular}{|c|c|c|c|c|c|c|c|c|c|}
\hline \multirow{2}{*}{ analyte } & \multirow{2}{*}{ units } & \multicolumn{2}{|c|}{ Test 3 Batch 1} & \multicolumn{2}{|c|}{ Test 3 Batch 2} & \multicolumn{2}{|c|}{ Test 4 Batch1 } & \multicolumn{2}{|c|}{ Test 4 Batch2 } \\
\hline & & initial & final & initial & final & initial & final & initial & final \\
\hline $\mathrm{Ag}$ & ug/g & $<9.59 E+00$ & $<9.45 E+00$ & $<9.50 E+00$ & $<9.56 E+00$ & $<9.59 E+00$ & $<9.39 E+00$ & $<9.48 E+00$ & $<9.56 E+00$ \\
\hline $\mathrm{Al}$ & ug/g & $1.63 \mathrm{E}+03$ & $4.65 \mathrm{E}+02$ & $5.66 \mathrm{E}+02$ & $6.12 \mathrm{E}+01$ & $2.97 \mathrm{E}+02$ & $1.86 \mathrm{E}+02$ & $6.36 \mathrm{E}+01$ & $1.53 \mathrm{E}+01$ \\
\hline B & ug/g & $<1.34 E+00$ & $<1.33 E+00$ & $<1.33 E+00$ & $<1.34 E+00$ & $<1.35 E+00$ & $<1.32 E+00$ & $<1.33 E+00$ & $<1.34 E+00$ \\
\hline $\mathrm{Ba}$ & ug/g & $3.94 \mathrm{E}+00$ & $1.16 \mathrm{E}+00$ & 8.18E-01 & 3.78E-01 & $2.02 \mathrm{E}+01$ & $1.20 \mathrm{E}+01$ & $5.78 \mathrm{E}+00$ & $1.37 \mathrm{E}+00$ \\
\hline Be & ug/g & $<5.30 E-02$ & $<5.30 E-02$ & $<5.30 E-02$ & $<5.30 E-02$ & $<5.30 E-02$ & $<5.20 E-02$ & $<5.30 E-02$ & $<5.30 E-02$ \\
\hline Ca & ug/g & $2.53 \mathrm{E}+01$ & $1.31 \mathrm{E}+01$ & $6.69 \mathrm{E}+00$ & $6.53 \mathrm{E}+00$ & $8.56 \mathrm{E}+01$ & $3.13 \mathrm{E}+01$ & $1.34 \mathrm{E}+01$ & $6.18 \mathrm{E}+00$ \\
\hline Ce & ug/g & $<4.71 E+00$ & $<4.64 E+00$ & $<4.67 E+00$ & $<4.69 E+00$ & $<4.71 E+00$ & $<4.61 E+00$ & $<4.65 E+00$ & $<4.69 E+00$ \\
\hline Co & ug/g & $<6.46 E-01$ & $<6.36 E-01$ & $<6.40 E-01$ & $<6.44 E-01$ & $<6.46 E-01$ & $<6.33 E-01$ & $<6.39 E-01$ & $<6.44 E-01$ \\
\hline $\mathrm{Cr}$ & ug/g & $5.69 \mathrm{E}+00$ & $4.47 \mathrm{E}+00$ & $1.38 E+00$ & $<6.77 E-01$ & $7.77 \mathrm{E}+00$ & $6.44 \mathrm{E}+00$ & $1.39 \mathrm{E}+00$ & $2.04 \mathrm{E}+00$ \\
\hline $\mathrm{Cu}$ & ug/g & $2.66 \mathrm{E}+00$ & $1.25 \mathrm{E}+00$ & 8.78E-01 & $<4.18 E-01$ & $<4.20 E-01$ & $<4.11 E-01$ & $<4.15 E-01$ & $<4.18 E-01$ \\
\hline $\mathrm{Fe}$ & ug/g & $3.82 \mathrm{E}+02$ & $9.48 \mathrm{E}+01$ & $1.49 \mathrm{E}+02$ & $1.75 \mathrm{E}+01$ & $6.47 \mathrm{E}+02$ & $5.66 \mathrm{E}+02$ & $3.96 \mathrm{E}+02$ & $1.15 \mathrm{E}+02$ \\
\hline Gd & ug/g & $<5.19 E-01$ & $<5.12 E-01$ & $<5.15 E-01$ & $<5.18 E-01$ & $<5.19 E+00$ & $<5.09 E+00$ & $<5.13 E-01$ & $<5.18 E-01$ \\
\hline K & ug/g & $<1.71 E+01$ & $<1.68 E+01$ & $<1.69 E+01$ & $<1.70 E+01$ & $<1.71 E+01$ & $<1.67 E+01$ & $<1.69 E+01$ & $<1.70 E+01$ \\
\hline $\mathrm{La}$ & ug/g & $<4.46 E-01$ & $<4.40 E-01$ & $<4.42 E-01$ & $<4.45 E-01$ & $<4.46 E-01$ & $<4.37 E-01$ & $<4.41 E-01$ & $<4.45 E-01$ \\
\hline $\mathrm{Li}$ & ug/g & $6.19 \mathrm{E}-01$ & 4.92E-01 & $<4.42 E-01$ & $<4.45 E-01$ & $5.81 \mathrm{E}+00$ & $3.59 \mathrm{E}+00$ & $1.66 \mathrm{E}+00$ & $1.42 \mathrm{E}+00$ \\
\hline $\mathrm{Mg}$ & ug/g & $1.01 \mathrm{E}+01$ & $5.95 \mathrm{E}+00$ & $1.76 \mathrm{E}+00$ & $1.48 \mathrm{E}+00$ & $4.79 \mathrm{E}+00$ & $3.63 \mathrm{E}+00$ & $1.72 \mathrm{E}+00$ & 5.98E-01 \\
\hline $\mathrm{Mn}$ & ug/g & $2.61 \mathrm{E}+02$ & $6.66 \mathrm{E}+01$ & 4.73E+01 & $5.08 \mathrm{E}+00$ & $1.92 \mathrm{E}+02$ & $1.81 \mathrm{E}+02$ & $5.28 \mathrm{E}+01$ & $1.14 \mathrm{E}+01$ \\
\hline Mo & ug/g & $<1.78 E+00$ & $<1.76 E+00$ & $<1.77 E+00$ & $<1.78 E+00$ & $<1.78 E+00$ & $<1.75 E+00$ & $<1.76 E+00$ & $<1.78 E+00$ \\
\hline $\mathrm{Na}$ & ug/g & $3.91 \mathrm{E}+02$ & $3.94 \mathrm{E}+02$ & $3.85 \mathrm{E}+01$ & $2.80 \mathrm{E}+01$ & $5.92 \mathrm{E}+02$ & $5.92 \mathrm{E}+02$ & $8.02 \mathrm{E}+01$ & $7.66 \mathrm{E}+01$ \\
\hline $\mathrm{Ni}$ & ug/g & $1.50 \mathrm{E}+01$ & $9.11 E+00$ & $6.39 E+00$ & $<3.02 E+00$ & $<3.03 E+00$ & $<2.97 E+00$ & $<3.00 E+00$ & $<3.02 E+00$ \\
\hline $\mathrm{P}$ & ug/g & $<5.77 E+00$ & $<5.68 E+00$ & $<5.71 E+00$ & $<5.75 E+00$ & $<5.77 E+00$ & $<5.65 E+00$ & $<5.70 E+00$ & $<5.75 E+00$ \\
\hline $\mathrm{Pb}$ & ug/g & $<4.77 E+00$ & $<4.70 E+00$ & $<4.72 E+00$ & $<4.75 E+00$ & $<4.77 E+00$ & $<4.67 E+00$ & $<4.71 E+00$ & $<4.75 E+00$ \\
\hline $\mathrm{S}$ & ug/g & $<4.99 E+01$ & $<4.92 E+01$ & $<4.95 E+01$ & $<4.98 E+01$ & $<5.00 E+01$ & $<4.89 E+01$ & $<4.94 E+01$ & $<4.98 E+01$ \\
\hline $\mathrm{Sb}$ & ug/g & $<8.50 E+00$ & $<8.38 E+00$ & $<8.43 E+00$ & $<8.47 E+00$ & $<8.50 E+00$ & $<8.33 E+00$ & $<8.41 E+00$ & $<8.48 E+00$ \\
\hline Sn & ug/g & $<3.74 E+00$ & $<3.68 E+00$ & $<3.70 E+00$ & $<3.72 E+00$ & $<3.74 E+00$ & $<3.66 E+00$ & $<3.69 E+00$ & $<3.73 E+00$ \\
\hline $\mathrm{Sr}$ & ug/g & $1.88 \mathrm{E}+00$ & $6.66 \mathrm{E}-01$ & 3.43E-01 & $2.66 \mathrm{E}-01$ & $1.01 \mathrm{E}+01$ & $6.00 \mathrm{E}+00$ & $2.47 \mathrm{E}+00$ & 5.85E-01 \\
\hline Th & ug/g & $<3.65 E+00$ & $<3.60 E+00$ & $7.01 \mathrm{E}+00$ & $<3.64 E+00$ & $4.93 \mathrm{E}+00$ & $4.18 \mathrm{E}+00$ & $<3.61 E+00$ & $<3.64 E+00$ \\
\hline $\mathrm{Ti}$ & ug/g & 5.19E-01 & $1.18 \mathrm{E}-01$ & 5.94E-01 & $9.29 \mathrm{E}-02$ & $2.34 \mathrm{E}+00$ & $1.36 \mathrm{E}+00$ & $9.55 \mathrm{E}-01$ & 2.59E-01 \\
\hline $\mathrm{U}$ & ug/g & $6.43 \mathrm{E}+01$ & $3.06 \mathrm{E}+01$ & $<2.15 E+01$ & $<2.17 E+01$ & $1.24 \mathrm{E}+03$ & $9.36 \mathrm{E}+02$ & $1.91 \mathrm{E}+02$ & $4.76 \mathrm{E}+01$ \\
\hline V & ug/g & $<3.13 E-01$ & $<3.08 E-01$ & $<3.10 E-01$ & $<3.12 E-01$ & $<3.13 E-01$ & $<3.06 E-01$ & $<3.09 E-01$ & $<3.12 E-01$ \\
\hline $\mathrm{Zr}$ & ug/g & $1.26 \mathrm{E}+01$ & $2.40 \mathrm{E}+00$ & $3.69 \mathrm{E}+00$ & $<3.65 E-01$ & $5.24 \mathrm{E}+01$ & $2.72 \mathrm{E}+01$ & $1.19 \mathrm{E}+01$ & $2.55 \mathrm{E}+00$ \\
\hline $\mathrm{Hg}$ & ug/g & $<3.66 E+00$ & $<3.61 E+00$ & $<3.63 E+00$ & $<3.65 E+00$ & $<3.66 E+00$ & $<3.59 E+00$ & $<3.62 E+00$ & $<3.65 E+00$ \\
\hline Co & ug/g & $1.47 \mathrm{E}-01$ & $<9.84 E-02$ & $<9.90 E-02$ & $<9.95 E-02$ & $<5.00 E-01$ & $<4.89 E-01$ & $<4.94 E-01$ & $<9.96 E-02$ \\
\hline $\mathrm{Pb}$ & ug/g & 4.06E-01 & 2.95E-01 & $<2.16 E-01$ & $1.55 \mathrm{E}+00$ & $2.48 \mathrm{E}+00$ & $1.99 \mathrm{E}+00$ & $2.73 E+00$ & 4.35E-01 \\
\hline $\mathrm{m}-232(\mathrm{Th})$ & ug/g & $2.67 \mathrm{E}+00$ & 5.58E-01 & $6.04 \mathrm{E}+00$ & $6.55 \mathrm{E}-01$ & $<3.33 E-01$ & 8.54E-01 & $1.36 \mathrm{E}+00$ & 4.61E-01 \\
\hline $\mathrm{m}-233(\mathrm{U})$ & ug/g & $8.00 \mathrm{E}-02$ & $<6.56 E-02$ & $<6.60 E-02$ & $<6.64 E-02$ & $<3.33 E-01$ & $<3.26 E-01$ & $<3.29 E-01$ & $<6.64 E-02$ \\
\hline $\mathrm{m}-234(\mathrm{U})$ & ug/g & 1.03E-01 & $<6.56 E-02$ & $<6.60 E-02$ & $<6.64 E-02$ & $<3.33 E-01$ & $<3.26 E-01$ & $<3.29 E-01$ & $<6.64 E-02$ \\
\hline $\mathrm{m}-235(\mathrm{U})$ & ug/g & $1.07 \mathrm{E}+00$ & $3.60 \mathrm{E}-01$ & $<3.30 E-01$ & $<3.32 E-01$ & $8.26 \mathrm{E}+00$ & $5.99 \mathrm{E}+00$ & $<1.65 E+00$ & $<3.32 E-01$ \\
\hline $\mathrm{m}-236(\mathrm{U})$ & ug/g & $1.47 \mathrm{E}-01$ & $<9.84 E-02$ & $<9.90 E-02$ & $<9.95 E-02$ & $<5.00 E-01$ & $<4.89 E-01$ & $<4.94 E-01$ & $<9.96 E-02$ \\
\hline m-237 (Np) & ug/g & 8.70E-02 & $<6.56 E-02$ & $<6.60 E-02$ & $<6.64 E-02$ & $<3.33 E-01$ & $<3.26 E-01$ & $<3.29 E-01$ & $<6.64 E-02$ \\
\hline m-238 (U,Pu) & ug/g & $6.57 \mathrm{E}+01$ & $2.38 \mathrm{E}+01$ & $8.44 \mathrm{E}+00$ & $1.08 \mathrm{E}+00$ & $1.22 \mathrm{E}+03$ & $9.45 E+02$ & $1.76 \mathrm{E}+02$ & $4.72 \mathrm{E}+01$ \\
\hline $\mathrm{m}-239(\mathrm{Pu})$ & ug/g & $3.80 \mathrm{E}-01$ & $1.31 \mathrm{E}-01$ & $1.60 \mathrm{E}-01$ & $<6.64 E-02$ & $<3.33 E-01$ & $<3.26 E-01$ & $<3.29 E-01$ & $<6.64 E-02$ \\
\hline $\mathrm{m}-240(\mathrm{Pu})$ & ug/g & $<6.66 E-02$ & $<6.56 E-02$ & $<6.60 E-02$ & $<6.64 E-02$ & $<3.33 E-01$ & $<3.26 E-01$ & $<3.29 E-01$ & $<6.64 E-02$ \\
\hline Pu-238 & $\mathrm{dpm} / \mathrm{g}$ & $1.23 \mathrm{E}+06$ & $2.64 \mathrm{E}+05$ & $5.57 \mathrm{E}+05$ & $6.29 \mathrm{E}+04$ & $1.28 \mathrm{E}+04$ & $2.89 \mathrm{E}+04$ & $3.58 \mathrm{E}+04$ & $1.33 \mathrm{E}+04$ \\
\hline Pu-239/240 & $\mathrm{dpm} / \mathrm{g}$ & $7.72 \mathrm{E}+04$ & $1.75 \mathrm{E}+04$ & $2.84 \mathrm{E}+04$ & $3.25 \mathrm{E}+03$ & $4.98 \mathrm{E}+03$ & $1.15 \mathrm{E}+04$ & $8.85 E+03$ & $4.26 \mathrm{E}+03$ \\
\hline Sr-90 & $\mathrm{dpm} / \mathrm{g}$ & $1.48 \mathrm{E}+08$ & $7.38 \mathrm{E}+07$ & $3.80 \mathrm{E}+07$ & $2.23 \mathrm{E}+07$ & $9.24 \mathrm{E}+08$ & $6.86 \mathrm{E}+08$ & $2.18 \mathrm{E}+08$ & $4.09 \mathrm{E}+07$ \\
\hline
\end{tabular}




\subsection{Deposition Tank Chemistry}

The Deposition Tank vessels contained portions of the two batches of Decomposition Module effluent slurry that were $\mathrm{pH}$ adjusted to approximately $1 \mathrm{M}$ free hydroxide. Table 3-6 contains the results for the soluble components in the Deposition Tank after two weeks of storage at $50{ }^{\circ} \mathrm{C}$. For these UV light tests, the concentrations of the major soluble Deposition Tank components are in general agreement with the tests without UV light.

Table 3-6: Deposition Tank Supernate Chemistry for ECC Actual Waste Tests 3 and 4

\begin{tabular}{|c|c|c|c|}
\hline analyte & units & $\begin{array}{c}\text { Test } 3 \\
\text { average }\end{array}$ & $\begin{array}{c}\text { Test } 4 \\
\text { average }\end{array}$ \\
\hline Oxalate & $\mathrm{mg} / \mathrm{L}$ & $3.61 \mathrm{E}+02$ & $3.19 \mathrm{E}+02$ \\
\hline $\mathrm{OH}$ & M & 9.97E-01 & 9.15E-01 \\
\hline $\mathrm{Ag}$ & $\mathrm{mg} / \mathrm{L}$ & $<6.58 E-01$ & $<6.38 E-01$ \\
\hline $\mathrm{Al}$ & $\mathrm{mg} / \mathrm{L}$ & $5.22 \mathrm{E}+02$ & $8.80 \mathrm{E}+01$ \\
\hline B & $\mathrm{mg} / \mathrm{L}$ & $<9.10 E-01$ & $<8.82 E-01$ \\
\hline $\mathrm{Ba}$ & $\mathrm{mg} / \mathrm{L}$ & $<2.34 E-01$ & $<2.27 E-01$ \\
\hline $\mathrm{Ca}$ & $\mathrm{mg} / \mathrm{L}$ & $1.38 \mathrm{E}+00$ & 7.72E-01 \\
\hline $\mathrm{Cd}$ & $\mathrm{mg} / \mathrm{L}$ & $<2.88 E-01$ & $<2.80 E-01$ \\
\hline $\mathrm{Ce}$ & $\mathrm{mg} / \mathrm{L}$ & $<3.19 E+00$ & $<3.09 E+00$ \\
\hline $\mathrm{Cr}$ & $\mathrm{mg} / \mathrm{L}$ & $2.55 \mathrm{E}+00$ & $2.89 \mathrm{E}+00$ \\
\hline $\mathrm{Cu}$ & $\mathrm{mg} / \mathrm{L}$ & $<2.88 E-01$ & $<2.80 E-01$ \\
\hline $\mathrm{Fe}$ & $\mathrm{mg} / \mathrm{L}$ & $2.50 \mathrm{E}+00$ & $2.58 \mathrm{E}+00$ \\
\hline Gd & $\mathrm{mg} / \mathrm{L}$ & $<9.73 E-01$ & $<9.44 E-01$ \\
\hline K & $\mathrm{mg} / \mathrm{L}$ & $<1.35 E+01$ & $<1.31 E+01$ \\
\hline $\mathrm{La}$ & $\mathrm{mg} / \mathrm{L}$ & $<3.06 E-01$ & $<2.97 E-01$ \\
\hline $\mathrm{Li}$ & $\mathrm{mg} / \mathrm{L}$ & $<3.06 E-01$ & $1.21 \mathrm{E}+00$ \\
\hline $\mathrm{Mg}$ & $\mathrm{mg} / \mathrm{L}$ & 1.33E-01 & 1.32E-01 \\
\hline Mn & $\mathrm{mg} / \mathrm{L}$ & $<2.43 E-01$ & $<2.36 E-01$ \\
\hline $\mathrm{Na}$ & $\mathrm{mg} / \mathrm{L}$ & $2.61 \mathrm{E}+04$ & 2.77E+04 \\
\hline $\mathrm{Ni}$ & $\mathrm{mg} / \mathrm{L}$ & $<2.05 E+00$ & $<1.99 E+00$ \\
\hline $\mathrm{P}$ & $\mathrm{mg} / \mathrm{L}$ & $<7.39 E+00$ & $<7.16 E+00$ \\
\hline S & $\mathrm{mg} / \mathrm{L}$ & $<3.38 E+01$ & $<3.28 E+01$ \\
\hline $\mathrm{Si}$ & $\mathrm{mg} / \mathrm{L}$ & $9.23 \mathrm{E}+00$ & $3.34 \mathrm{E}+01$ \\
\hline
\end{tabular}

\begin{tabular}{|c|c|c|c|}
\hline analyte & units & $\begin{array}{c}\text { Test } 3 \\
\text { average }\end{array}$ & $\begin{array}{c}\text { Test } 4 \\
\text { average }\end{array}$ \\
\hline $\mathrm{Sr}$ & $\mathrm{mg} / \mathrm{L}$ & $<2.70 E-02$ & $<2.62 E-02$ \\
\hline Th & $\mathrm{mg} / \mathrm{L}$ & $<2.42 E+00$ & $<2.34 E+00$ \\
\hline $\mathrm{Ti}$ & $\mathrm{mg} / \mathrm{L}$ & $<1.71 E-01$ & $<1.66 E-01$ \\
\hline $\mathrm{U}$ & $\mathrm{mg} / \mathrm{L}$ & $2.54 \mathrm{E}+01$ & $7.84 \mathrm{E}+01$ \\
\hline $\mathrm{Zn}$ & $\mathrm{mg} / \mathrm{L}$ & 7.25E-01 & $<2.88 E-01$ \\
\hline $\mathrm{Zr}$ & $\mathrm{mg} / \mathrm{L}$ & $<2.52 E-01$ & $<2.45 E-01$ \\
\hline $\mathrm{Hg}$ & $\mathrm{mg} / \mathrm{L}$ & $<4.51 E-01$ & $<8.74 E-02$ \\
\hline Co & $\mathrm{mg} / \mathrm{L}$ & $<1.13 E-01$ & $<1.09 E-01$ \\
\hline $\mathrm{Pb}$ & $\mathrm{mg} / \mathrm{L}$ & $<9.01 E-02$ & $<8.74 E-02$ \\
\hline m-232 (Th) & $\mathrm{mg} / \mathrm{L}$ & $<1.13 E-01$ & $<1.09 E-01$ \\
\hline $\mathrm{m}-233(\mathrm{U})$ & $\mathrm{mg} / \mathrm{L}$ & $<4.51 E-02$ & $<4.37 E-02$ \\
\hline $\mathrm{m}-234(\mathrm{U})$ & $\mathrm{mg} / \mathrm{L}$ & $<4.51 E-02$ & $<4.37 E-02$ \\
\hline $\mathrm{m}-235(\mathrm{U})$ & $\mathrm{mg} / \mathrm{L}$ & 2.81E-01 & 5.05E-01 \\
\hline $\mathrm{m}-236(\mathrm{U})$ & $\mathrm{mg} / \mathrm{L}$ & 4.46E-02 & $<4.37 E-02$ \\
\hline m-237 (Np) & $\mathrm{mg} / \mathrm{L}$ & $<4.51 E-02$ & $<4.37 E-02$ \\
\hline m-238 (U,Pu) & $\mathrm{mg} / \mathrm{L}$ & $1.79 \mathrm{E}+01$ & $8.31 \mathrm{E}+01$ \\
\hline m-239 (Pu) & $\mathrm{mg} / \mathrm{L}$ & $<4.51 E-02$ & $<4.37 E-02$ \\
\hline $\mathrm{m}-240(\mathrm{Pu})$ & $\mathrm{mg} / \mathrm{L}$ & $<4.51 E-02$ & $<4.37 E-02$ \\
\hline $\mathrm{Pu}-238$ & $\mathrm{dpm} / \mathrm{mL}$ & $7.16 \mathrm{E}+04$ & $6.89 \mathrm{E}+02$ \\
\hline $\mathrm{Pu}-239 / 240$ & $\mathrm{dpm} / \mathrm{mL}$ & $4.00 \mathrm{E}+03$ & $2.32 \mathrm{E}+02$ \\
\hline Sr-90 & $\mathrm{dpm} / \mathrm{mL}$ & $2.57 \mathrm{E}+05$ & $4.38 \mathrm{E}+04$ \\
\hline Cs-137 & $\mathrm{dpm} / \mathrm{mL}$ & $1.03 \mathrm{E}+06$ & $1.50 \mathrm{E}+07$ \\
\hline
\end{tabular}




\subsection{UV and Non-UV Test Comparisons}

Figure 3-5 shows an example of the $\mathrm{pH}$ behavior for two similar OA decomposition batches where the primary difference was the use or non-use of UV light. The specific batch shown in this comparison was the second batch of the two tests using Tank 5F sludge. This case was chosen for the relatively good agreement between the batch volume and starting $\mathrm{pH}$ of the two tests. The specific observation from Figure 3-5 is that, when UV light was used, the decomposition endpoint was achieved in approximately half of the time as when UV light was not used. This, however, may be an overly optimistic result in favor of the use of UV light.

A qualitative observation results from the entire ECC RWT program is that the UV light reduces the time required during the initial part of the decomposition batch, more quickly bringing the $\mathrm{pH}$ up to $\sim 4$ and commencing precipitation of sludge solids. From this testing, the evidence is unclear as to whether the UV light provides benefit in the later stages of each OA decomposition batch. Reduction of the effect of UV light is expected at later portions of a decomposition batch because the slurry becomes opaque to the transmission of UV light as more sludge solids are precipitated.

It is difficult to make comparisons like that of Figure 3-5 for all OA decomposition batches. As noted in previous sections, there are differences between the specific batch feeds and uncertainties in the OA concentration at the start of the decomposition step. As discussed in Section 3.3, there also is uncertainty in the relative amount of ozone fed to the Decomposition Module between the tests with and without UV light. Due to these difficulties, strong quantitative relationships between the use of UV light and the effectiveness of OA decomposition cannot be formulated from this testing.

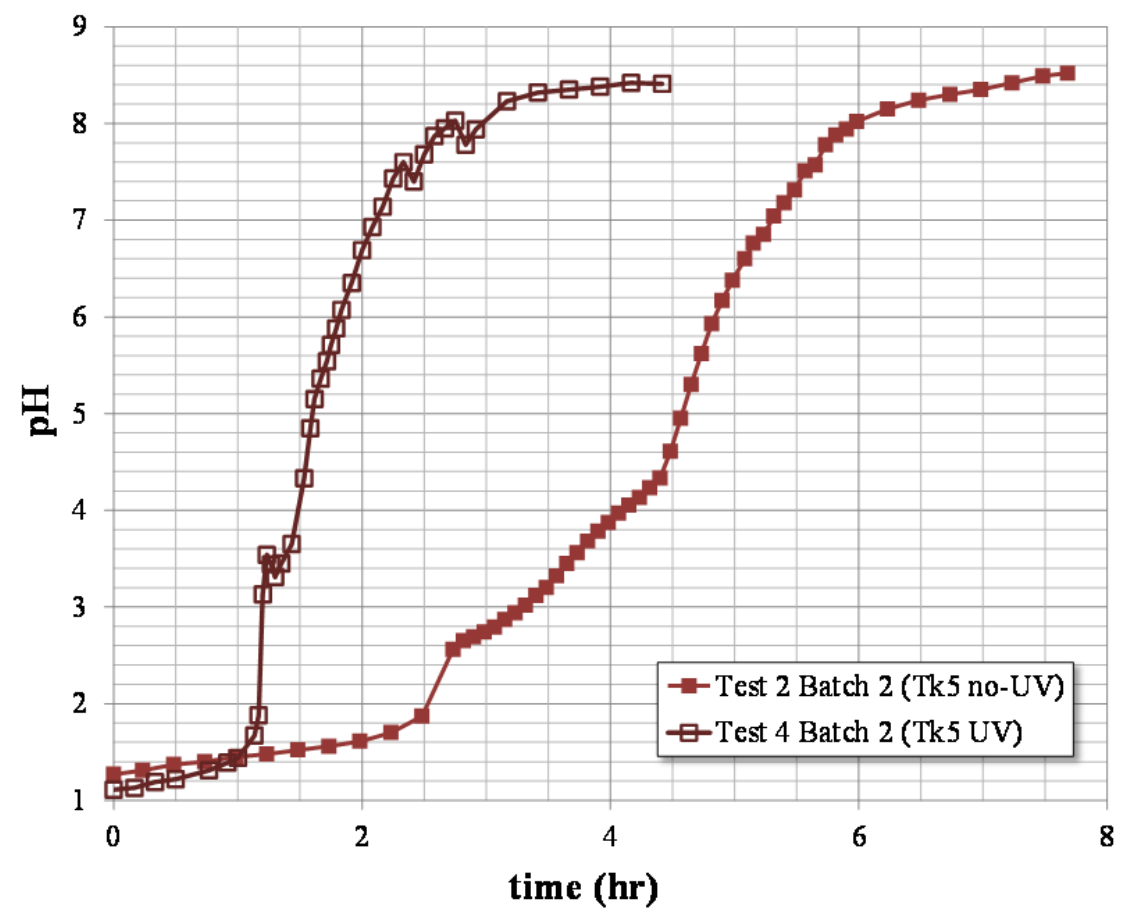

Figure 3-5: Comparison of pH change during UV and no-UV light tests for Tank 5F Tests, second dissolution batch 
Figure 3-6 and Figure 3-7 display the soluble concentrations for plutonium and uranium, respectively, at different stages of the ECC processing. Results for all four tests are included in the comparisons. "Post Sludge Dissolution" and "Post Oxalate Decomposition" categories are analogous to the columns entitled "initial" and "final", respectively, in Table 3-1 through Table 3-4 in this report and Table 3-11 through Table 3-16 in Ref. 7. The "Post pH Adjust \& Storage" category contains the data for the $\mathrm{pH}$ adjusted non-evaporated Deposition Tank cases from Table 3-6 of this report and various tables from Ref. 7.

For both the Post Sludge Dissolution and Post Oxalate Decomposition samples, the initial batch for each test resulted in the highest soluble uranium and plutonium concentrations. In Figure 3-6 and Figure 3-7, the results for the first batch for each test are the fully opaque symbols and the results for the other batches are the ghosted symbols.

The results in Figure 3-6 and Figure 3-7 suggest that uranium and plutonium continue to precipitate in the Deposition Tank to an extent beyond the precipitation in the Decomposition Module. This is likely due to the additional $\mathrm{pH}$ adjustment to $1 \mathrm{M}$ free hydroxide and the time required to reach equilibrium.

For plutonium, the two starting test sludges (Tank $12 \mathrm{H}$ or Tank 5F) result in soluble plutonium concentrations in the Deposition Tank that differ significantly from each other. This difference in Deposition Tank Pu concentration is noted in spite of the similar and overlapping levels of soluble Pu concentration post sludge dissolution. For uranium, the opposite effect was noted. The same approximate level of soluble uranium was noted in the Deposition Tank regardless of test or feed sludge material. This is observed even though the two feed materials exhibit different soluble uranium concentrations at the post sludge dissolution stage.

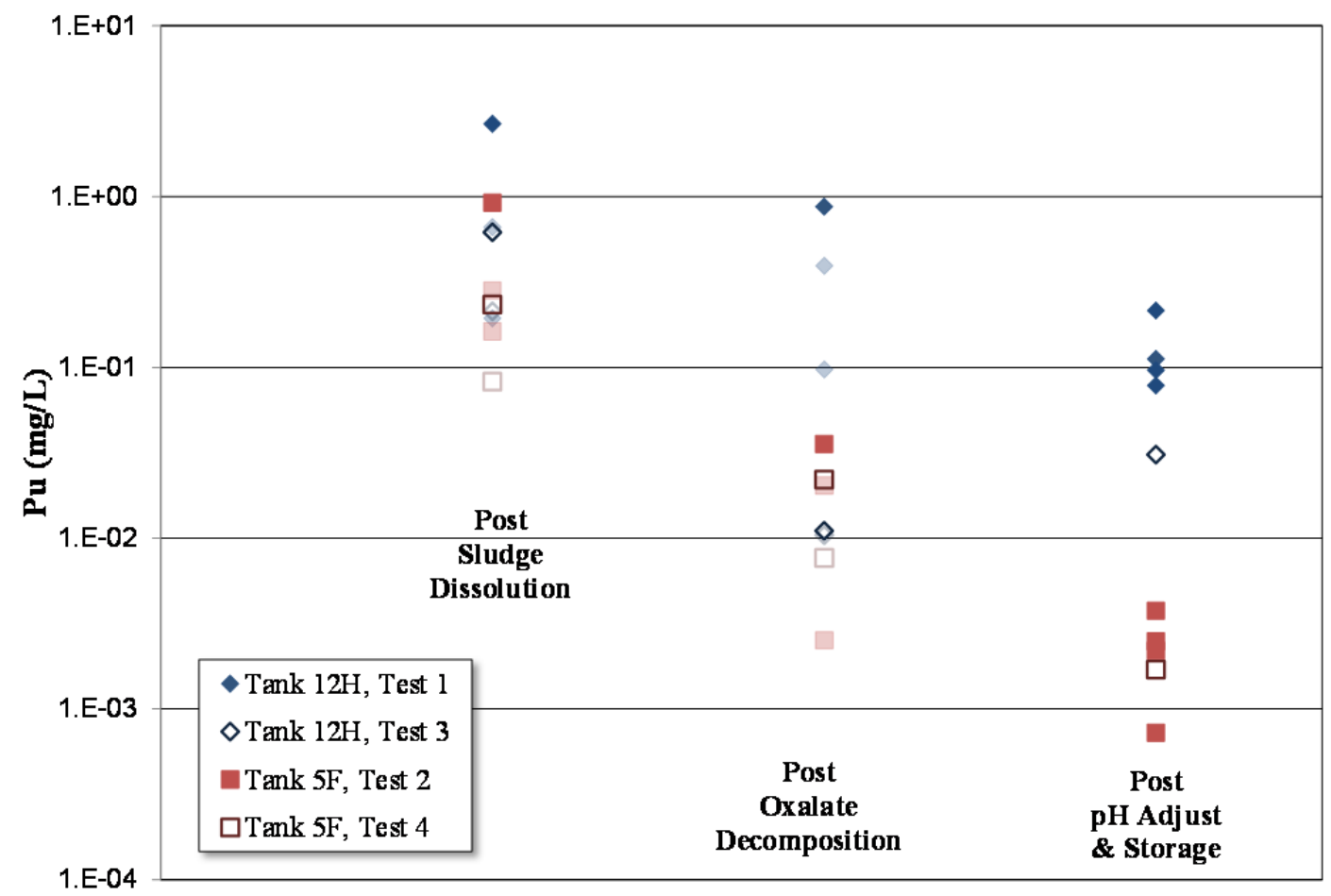

Figure 3-6: Soluble plutonium observed after sludge dissolution and after oxalate decomposition, compared with no-evaporation decomposition tank measurements 


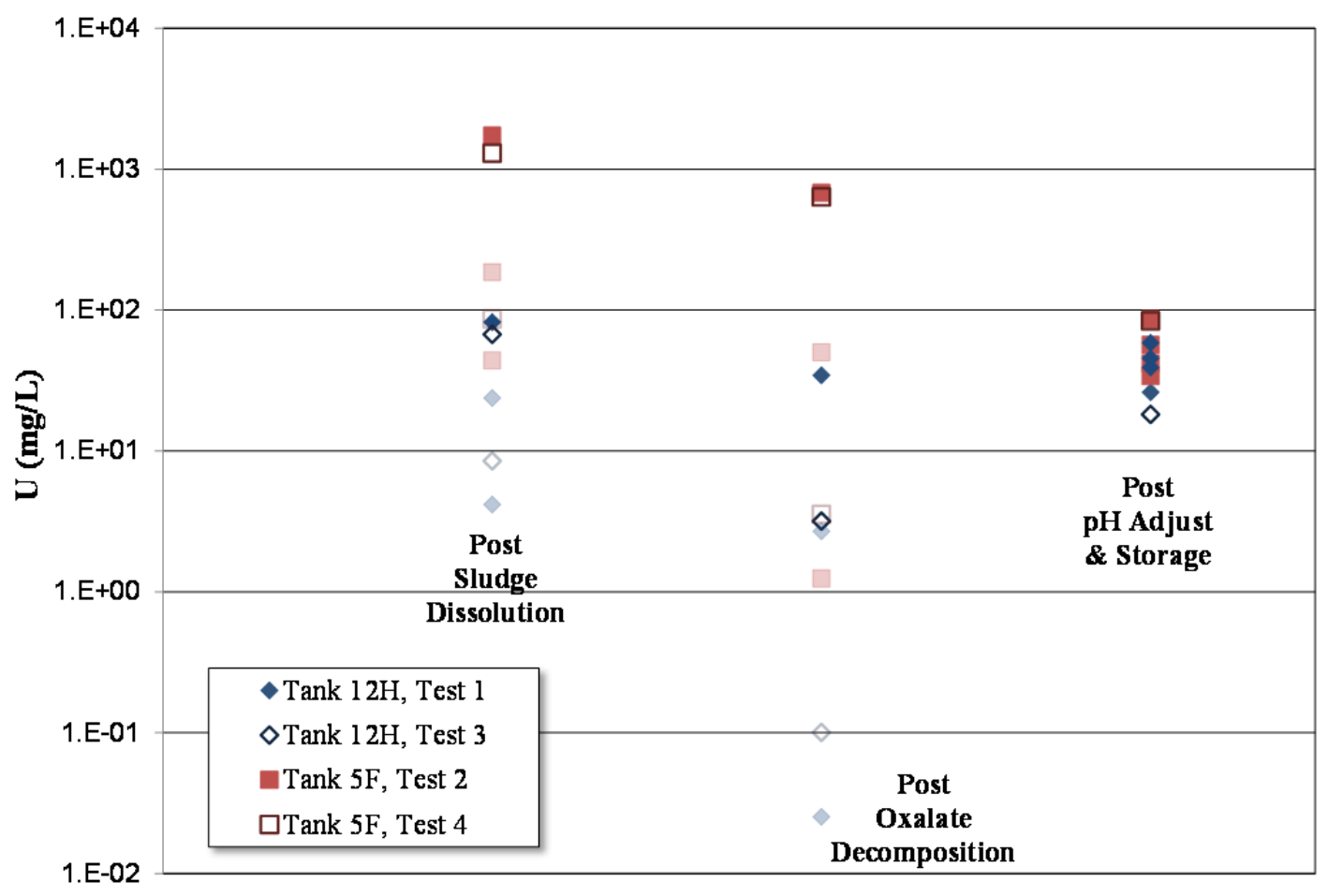

Figure 3-7: Soluble uranium observed after sludge dissolution and after oxalate decomposition, compared with no-evaporation decomposition tank measurements

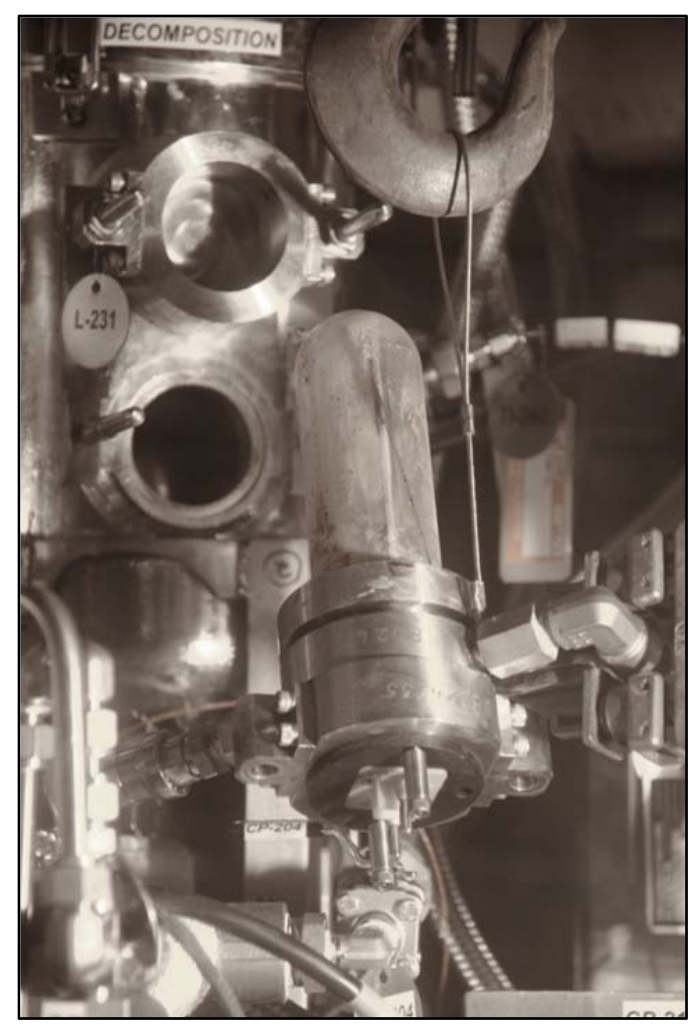

Figure 3-8: UV light after Test 4 Batch 2, prior to cleaning 
Contrary to observations during ECC testing on a larger scale using simulants, ${ }^{14}$ there did not appear to be a complete and persistent opaque coating on the UV light housing. As seen in Figure 3-8, material was present on the outer quartz tube but it did not completely block visibility through the quartz tube. Any reduction of the influence of the UV light on the decomposition of OA was likely influenced more by the opacity of the bulk solution than by a surface coating on the UV light housing. A potential reason for the apparent lack of build-up of solids on the quartz tube is that the design of the ECC RWT equipment allowed for the temperature at the surface of the UV light housing to be kept slightly cooler than the surrounding fluid.

\subsection{Conclusions}

The use of UV light was seen to aid in the decomposition of OA, generally reducing the time required to reach the target of $<100 \mathrm{mg} / \mathrm{L}$ oxalate. This effect was the most pronounced during the initial part of the decomposition batches, when the $\mathrm{pH}$ is $<4$. Due to uncertainties, it is unclear whether the UV light provides benefit in the later stages of each OA decomposition batch. Testing of the deposition tank storage of the ECC product resulted in analogous soluble concentrations regardless of the use or non-use of UV light in the ECC reactor.

\subsection{Quality Assurance}

The following notebooks and electronic records contain the data taken during the ECC RWT project: SRNL-NB-2009-00155, SRNL-NB-2011-00049, SRNL-NB-2011-00105 and SRNLEM-2011-00007.

\subsection{Acknowledgements}

This effort involved the support of many people within SRNL, SRR, and AREVA. Full treatment of acknowledgements for this effort is included in Reference 7. 


\subsection{References}

${ }^{1}$ J. A Pike,. N. P. Badheka, E. T. Ketusky, "Flowsheet for SRS Waste Tank Heel Removal Using Oxalic Acid,” WSRC-TR-2004-00317, Rev. 0, November 2004.

${ }^{2}$ K. Adu-Wasu, , M. J. Barnes, N. E. Bibler, J. R. Cantrell, F. F. Fondeur, B. A. Hamm, C. C. Herman, D. T. Hobbs, E. T. Ketusky, M. Singleton, M. E. Stallings, W. E. Stevens, and B. J. Wiersma, "Waste Tank Heel Chemical Cleaning Summary,” WSRC-TR-2003-00401, Rev. 0, September 2003.

${ }^{3}$ E. T. Ketusky, "Determination of an Alternative Technology for HLW Tank Chemical Cleaning,” WSRC-STI-2007-00587, Rev. 0, October 2007.

${ }^{4}$ M. S. Hay and D. C. Koopman, "Review of Alternative Enhanced Chemical Cleaning Options for SRS Waste Tanks,” SRNL-STI-2009-00500, Rev. 0, August 27, 2009.

${ }^{5}$ C. J. Martino and W. D. King, "Task Technical and Quality Assurance Plan for Real Waste Testing to Support Enhanced Chemical Cleaning for Sludge Heel Removal,” SRNL-RP-200800602, Rev. 2, March 21, 2011.

${ }^{6}$ A. G. Hansen, “Enhanced Chemical Cleaning (ECC) Real Waste Testing,” HLE-TTR-2008-033, Rev. 3, December 13, 2010.

${ }^{7}$ C. J. Martino and W. D. King, "Testing of Enhanced Chemical Cleaning of SRS Actual Waste Tank 5F and Tank 12H Sludges," SRNL-STI-2011-00360, Rev. 0, August 2011.

8 “ECC Real Waste Testing Equipment Process Flow Diagram,” AREVA, 02-9124816D-005, February 4, 2011.

${ }^{9}$ W. E. Narrows, "Statement of Work: Enhanced Chemical Cleaning Real Waste Test Equipment,” G-SOW-A-00049, Rev. 1, October 7, 2009.

10 "Real Waste Testing Technical Requirements Document and Conceptual Design Basis," AREVA, 51-9084868-000, July 22, 2008.

11 "Enhanced Chemical Cleaning Real Waste Test Equipment Project Plan,” AREVA, PP3001988-000B, September 30, 2009.

12 "ECC-RWT Equipment Piping and Instrumentation Diagram,” AREVA, 02-9125569D-005, January 5, 2011.

13 “Enhanced Chemical Cleaning Real Waste Test Equipment Operating Procedure,” Manual L29, Procedure ITS-0170, Revision 2, June 21, 2011.

${ }^{14}$ W. T. Hix and S. E. Evans, "ECC-HST Task 1 and 2 Report: UV Light Evaluation,” AREVA 51-9159879-003, June 28, 2011. 
A.

Appendix A. Dissolution, Decomposition, and Evaporation Process Data 
Table A-1: Test 3 (Tank 12H Sludge) OA Batch 1 Decomposition Module Data

\begin{tabular}{|c|c|c|c|c|c|c|}
\hline $\begin{array}{c}\text { Date/Time } \\
(\mathrm{mm} / \mathrm{dd} / \mathrm{yy} \text { hh:mm) }\end{array}$ & $\begin{array}{c}\text { Run Time } \\
\text { (hr) }\end{array}$ & $\begin{array}{c}\text { Temperature } \\
\left({ }^{\circ} \mathrm{C}\right)\end{array}$ & $\begin{array}{l}\text { Pressure } \\
\text { (psi) }\end{array}$ & $\begin{array}{c}\text { Flow } \\
\text { (gal/min) }\end{array}$ & pH & $\begin{array}{l}\text { ORP } \\
(\mathbf{m V})\end{array}$ \\
\hline 08/18/11 07:27 & -- & 38.9 & 0.0 & 1.52 & 1.60 & 230 \\
\hline 08/18/11 08:00 & -- & 63.5 & 0.0 & 1.45 & 1.61 & 138 \\
\hline 08/18/11 08:15 & -- & 68.8 & 0.0 & 1.45 & 1.63 & 146 \\
\hline 08/18/11 08:30 & 0.00 & 70.6 & 8.0 & 1.57 & 1.65 & 249 \\
\hline 08/18/11 08:45 & 0.25 & 70.1 & 8.0 & 1.57 & 1.67 & 370 \\
\hline 08/18/11 09:00 & 0.50 & 70.0 & 8.2 & 1.53 & 1.69 & 330 \\
\hline 08/18/11 09:15 & 0.75 & 70.0 & 8.2 & 1.52 & 1.76 & 319 \\
\hline 08/18/11 09:30 & 1.00 & 70.0 & 8.2 & 1.52 & 1.92 & 330 \\
\hline 08/18/11 09:37 & 1.12 & 70.0 & 8.0 & 1.52 & 2.31 & 344 \\
\hline 08/18/11 09:40 & 1.17 & 70.0 & 8.0 & 1.40 & 3.12 & 353 \\
\hline 08/18/11 09:45 & 1.25 & 70.0 & 8.0 & 1.40 & 3.59 & 328 \\
\hline 08/18/11 09:50 & 1.33 & 70.0 & 8.0 & 1.39 & 3.76 & 333 \\
\hline 08/18/11 09:55 & 1.42 & 70.0 & 8.0 & 1.38 & 3.84 & 544 \\
\hline 08/18/11 10:00 & 1.50 & 70.0 & 8.0 & 1.38 & 3.89 & 862 \\
\hline 08/18/11 10:15 & 1.75 & 70.0 & 8.5 & 1.35 & 3.90 & 874 \\
\hline 08/18/11 10:30 & 2.00 & 70.0 & 8.3 & 1.35 & 3.91 & 883 \\
\hline 08/18/11 10:45 & 2.25 & 70.0 & 8.1 & 1.35 & 3.98 & 924 \\
\hline 08/18/11 11:00 & 2.50 & 70.0 & 8.5 & 1.35 & 4.11 & 985 \\
\hline 08/18/11 11:15 & 2.75 & 70.0 & 7.5 & 1.38 & 4.24 & 929 \\
\hline 08/18/11 11:30 & 3.00 & 70.0 & 8.0 & 1.38 & 4.35 & 908 \\
\hline 08/18/11 11:45 & 3.25 & 70.0 & 8.2 & 1.40 & 4.46 & 875 \\
\hline 08/18/11 12:00 & 3.50 & 70.0 & 8.2 & 1.38 & 4.58 & 858 \\
\hline 08/18/11 12:15 & 3.75 & 70.0 & 8.2 & 1.38 & 4.73 & 840 \\
\hline 08/18/11 12:30 & 4.00 & 70.0 & 8.2 & 1.38 & 4.89 & 826 \\
\hline 08/18/11 12:45 & 4.25 & 70.0 & 8.1 & 1.37 & 5.09 & 809 \\
\hline 08/18/11 13:00 & 4.50 & 70.0 & 8.1 & 1.38 & 5.35 & 793 \\
\hline 08/18/11 13:05 & 4.58 & 70.0 & 8.0 & 1.38 & 5.44 & 786 \\
\hline 08/18/11 13:10 & 4.67 & 70.0 & 8.0 & 1.38 & 5.55 & 781 \\
\hline 08/18/11 13:15 & 4.75 & 70.0 & 7.7 & 1.38 & 5.66 & 779 \\
\hline 08/18/11 13:20 & 4.83 & 70.0 & 7.9 & 1.37 & 5.78 & 769 \\
\hline 08/18/11 13:25 & 4.92 & 70.0 & 7.9 & 1.38 & 5.93 & 769 \\
\hline 08/18/11 13:30 & 5.00 & 70.0 & 8.0 & 1.37 & 6.04 & 761 \\
\hline 08/18/11 13:36 & 5.10 & 70.0 & 8.0 & 1.38 & 6.26 & 747 \\
\hline 08/18/11 13:40 & 5.17 & 70.0 & 8.0 & 1.38 & 6.40 & 740 \\
\hline
\end{tabular}


Table A-1: Test 3 (Tank 12H Sludge) OA Batch 1 Decomposition Module Data

\begin{tabular}{|c|c|c|c|c|c|c|}
\hline $\begin{array}{c}\text { Date/Time } \\
\text { (mm/dd/yy hh:mm) }\end{array}$ & $\begin{array}{l}\text { Run Time } \\
\text { (hr) }\end{array}$ & $\begin{array}{c}\text { Temperature } \\
\left({ }^{\circ} \mathrm{C}\right)\end{array}$ & $\begin{array}{l}\text { Pressure } \\
\text { (psi) }\end{array}$ & $\begin{array}{c}\text { Flow } \\
\text { (gal/min) }\end{array}$ & pH & $\begin{array}{l}\text { ORP } \\
(\mathrm{mV})\end{array}$ \\
\hline 08/18/11 13:45 & 5.25 & 70.0 & 7.8 & 1.38 & 6.48 & 744 \\
\hline 08/18/11 13:50 & 5.33 & 70.0 & 8.0 & 1.38 & 6.60 & 744 \\
\hline 08/18/11 13:55 & 5.42 & 70.0 & 7.8 & 1.38 & 6.72 & 744 \\
\hline 08/18/11 14:00 & 5.50 & 70.0 & 8.0 & 1.38 & 6.81 & 746 \\
\hline 08/18/11 14:05 & 5.58 & 70.0 & 7.9 & 1.38 & 6.90 & 747 \\
\hline 08/18/11 14:10 & 5.67 & 70.0 & 7.9 & 1.38 & 6.99 & 752 \\
\hline 08/18/11 14:15 & 5.75 & 70.0 & 7.5 & 1.38 & 7.09 & 750 \\
\hline 08/18/11 14:20 & 5.83 & 70.0 & 7.5 & 1.38 & 7.21 & 749 \\
\hline 08/18/11 14:25 & 5.92 & 70.0 & 7.5 & 1.38 & 7.28 & 755 \\
\hline 08/18/11 14:30 & 6.00 & 70.0 & 7.5 & 1.38 & 7.39 & 759 \\
\hline 08/18/11 14:35 & 6.08 & 70.1 & 7.5 & 1.38 & 7.49 & 761 \\
\hline 08/18/11 14:40 & 6.17 & 70.0 & 7.5 & 1.38 & 7.58 & 758 \\
\hline 08/18/11 14:45 & 6.25 & 70.1 & 7.5 & 1.38 & 7.64 & 760 \\
\hline 08/18/11 14:55 & 6.42 & 70.0 & 7.5 & 1.38 & 7.74 & 762 \\
\hline 08/18/11 15:05 & 6.58 & 70.0 & 7.5 & 1.38 & 7.84 & 761 \\
\hline 08/18/11 15:15 & 6.75 & 70.0 & 7.5 & 1.39 & 7.95 & 765 \\
\hline 08/18/11 15:31 & 7.02 & 70.0 & 8.0 & 1.38 & 8.10 & 766 \\
\hline 08/18/11 15:45 & 7.25 & 70.0 & 8.0 & 1.38 & 8.25 & 774 \\
\hline 08/18/11 16:00 & 7.50 & 70.0 & 8.0 & 1.38 & 8.38 & 776 \\
\hline 08/18/11 16:15 & 7.75 & 70.0 & 8.0 & 1.37 & 8.48 & 764 \\
\hline 08/18/11 16:30 & 8.00 & 70.0 & 8.0 & 1.37 & 8.55 & 772 \\
\hline
\end{tabular}


Table A-2: Test 3 (Tank 12H Sludge) OA Batch 2 Decomposition Module Data

\begin{tabular}{|c|c|c|c|c|c|c|}
\hline $\begin{array}{c}\text { Date/Time } \\
\text { (mm/dd/yy hh:mm) }\end{array}$ & $\begin{array}{l}\text { Run Time } \\
\text { (hr) }\end{array}$ & $\begin{array}{c}\text { Temperature } \\
\left({ }^{\circ} \mathrm{C}\right)\end{array}$ & $\begin{array}{l}\text { Pressure } \\
\text { (psi) }\end{array}$ & $\begin{array}{c}\text { Flow } \\
\text { (gal/min) }\end{array}$ & pH & $\begin{array}{l}\text { ORP } \\
(\mathrm{mV})\end{array}$ \\
\hline 08/22/11 07:44 & - & 36.0 & -- & -- & 1.08 & -- \\
\hline 08/22/11 08:14 & - & 63.9 & 0.0 & 1.55 & 1.10 & 299 \\
\hline 08/22/11 08:30 & 0.00 & 70.6 & 8.0 & 1.53 & 1.13 & 547 \\
\hline 08/22/11 08:46 & 0.27 & 70.3 & 9.0 & 1.55 & 1.17 & 720 \\
\hline 08/22/11 09:00 & 0.50 & 70.0 & 8.0 & 1.55 & 1.19 & 722 \\
\hline 08/22/11 09:17 & 0.78 & 70.1 & 8.0 & 1.55 & 1.25 & 738 \\
\hline 08/22/11 09:30 & 1.00 & 70.0 & 8.0 & 1.55 & 1.31 & 667 \\
\hline 08/22/11 09:45 & 1.25 & 70.0 & 8.0 & 1.55 & 1.53 & 619 \\
\hline 08/22/11 09:50 & 1.33 & 70.0 & 8.0 & 1.55 & 2.73 & 660 \\
\hline 08/22/11 09:55 & 1.42 & 69.9 & 8.0 & 1.55 & 2.97 & 743 \\
\hline 08/22/11 10:00 & 1.50 & 69.9 & 8.2 & 1.54 & 2.92 & 787 \\
\hline 08/22/11 10:15 & 1.75 & 70.0 & 8.5 & 1.55 & 3.04 & 842 \\
\hline 08/22/11 10:30 & 2.00 & 70.0 & 9.0 & 1.38 & 3.15 & 849 \\
\hline 08/22/11 10:45 & 2.25 & 70.0 & 8.5 & 1.38 & 3.28 & 885 \\
\hline 08/22/11 11:00 & 2.50 & 70.0 & 8.5 & 1.38 & 3.41 & 823 \\
\hline 08/22/11 11:15 & 2.75 & 70.0 & 8.6 & 1.38 & 3.49 & 803 \\
\hline 08/22/11 11:30 & 3.00 & 70.0 & 8.6 & 1.38 & 3.63 & 846 \\
\hline 08/22/11 11:45 & 3.25 & 70.0 & 8.4 & 1.38 & 3.88 & 846 \\
\hline 08/22/11 11:55 & 3.42 & 70.0 & 8.2 & 1.38 & 4.16 & 771 \\
\hline 08/22/11 12:00 & 3.50 & 70.0 & 8.2 & 1.38 & 4.44 & 757 \\
\hline 08/22/11 12:06 & 3.60 & 70.0 & 8.3 & 1.38 & 5.07 & 723 \\
\hline 08/22/11 12:10 & 3.67 & 70.0 & 7.5 & 1.37 & 5.36 & 725 \\
\hline 08/22/11 12:15 & 3.75 & 70.0 & 8.0 & 1.38 & 5.90 & 758 \\
\hline 08/22/11 12:20 & 3.83 & 70.0 & 7.5 & 1.38 & 6.08 & 730 \\
\hline 08/22/11 12:25 & 3.92 & 70.0 & 7.5 & 1.39 & 6.23 & 786 \\
\hline 08/22/11 12:30 & 4.00 & 70.0 & 7.5 & 1.38 & 6.23 & 768 \\
\hline 08/22/11 12:35 & 4.08 & 70.0 & 7.6 & 1.38 & 6.27 & 809 \\
\hline 08/22/11 12:41 & 4.18 & 70.0 & 7.7 & 1.38 & 6.39 & 869 \\
\hline 08/22/11 12:45 & 4.25 & 70.0 & 7.8 & 1.38 & 6.39 & 852 \\
\hline 08/22/11 12:50 & 4.33 & 70.0 & 7.8 & 1.38 & 6.40 & 844 \\
\hline 08/22/11 12:55 & 4.42 & 70.0 & 8.0 & 1.38 & 6.42 & 864 \\
\hline 08/22/11 13:03 & 4.55 & 70.0 & 8.0 & 1.39 & 6.39 & 866 \\
\hline 08/22/11 13:15 & 4.75 & 70.0 & 8.0 & 1.39 & 6.41 & 860 \\
\hline 08/22/11 13:30 & 5.00 & 70.0 & 8.0 & 1.38 & 6.36 & 924 \\
\hline 08/22/11 13:45 & 5.25 & 70.0 & 8.0 & 1.38 & 6.36 & 904 \\
\hline 08/22/11 14:00 & 5.50 & 70.0 & 8.0 & 1.38 & 6.32 & 913 \\
\hline 08/22/11 14:15 & 5.75 & 70.0 & 8.0 & 1.38 & 6.31 & 924 \\
\hline 08/22/11 14:28 & 5.97 & 70.0 & 7.5 & 1.38 & 6.26 & 973 \\
\hline 08/22/11 14:55 & 6.42 & -- & -- & -- & -- & -- \\
\hline
\end{tabular}


Table A-3: Test 4 (Tank 5F Sludge) OA Batch 1 Decomposition Module Data

\begin{tabular}{|c|c|c|c|c|c|c|}
\hline $\begin{array}{c}\text { Date/Time } \\
\text { (mm/dd/yy hh:mm) }\end{array}$ & $\begin{array}{c}\text { Run Time } \\
\text { (hr) }\end{array}$ & $\begin{array}{c}\text { Temperature } \\
\left({ }^{\circ} \mathrm{C}\right)\end{array}$ & $\begin{array}{l}\text { Pressure } \\
\text { (psi) }\end{array}$ & $\begin{array}{c}\text { Flow } \\
\text { (gal/min) }\end{array}$ & pH & $\begin{array}{l}\text { ORP } \\
(\mathrm{mV})\end{array}$ \\
\hline 08/29/11 06:58 & -- & 25.5 & 0.0 & 1.50 & 1.23 & 262 \\
\hline 08/29/11 07:45 & 0.00 & 69.2 & 7.5 & 1.38 & 1.35 & 217 \\
\hline 08/29/11 07:50 & 0.08 & 70.7 & 8.0 & 1.39 & 1.37 & 253 \\
\hline 08/29/11 08:00 & 0.25 & 70.8 & 8.5 & 1.40 & 1.44 & 275 \\
\hline 08/29/11 08:15 & 0.50 & 70.0 & 7.3 & 1.40 & 1.68 & 293 \\
\hline 08/29/11 08:20 & 0.58 & 69.9 & 8.0 & 1.46 & 1.94 & 304 \\
\hline 08/29/11 08:22 & 0.62 & 69.9 & 8.0 & 1.46 & 2.11 & 311 \\
\hline 08/29/11 08:24 & 0.65 & 69.9 & 8.0 & 1.46 & 2.48 & 326 \\
\hline 08/29/11 08:26 & 0.68 & 69.9 & 8.0 & 1.48 & 2.99 & 345 \\
\hline 08/29/11 08:28 & 0.72 & 69.8 & 8.0 & 1.48 & 3.29 & 379 \\
\hline 08/29/11 08:30 & 0.75 & 70.0 & 8.0 & 1.48 & 3.39 & 442 \\
\hline 08/29/11 08:35 & 0.83 & 70.0 & 8.0 & 1.48 & 3.41 & 668 \\
\hline 08/29/11 08:40 & 0.92 & 70.0 & 8.0 & 1.47 & 3.55 & 676 \\
\hline 08/29/11 08:45 & 1.00 & 70.0 & 8.0 & 1.47 & 3.64 & 629 \\
\hline 08/29/11 08:50 & 1.08 & 70.0 & 7.9 & 1.47 & 3.72 & 587 \\
\hline 08/29/11 08:55 & 1.17 & 70.0 & 8.2 & 1.47 & 3.81 & 563 \\
\hline 08/29/11 09:00 & 1.25 & 70.0 & 8.3 & 1.47 & 3.89 & 540 \\
\hline 08/29/11 09:05 & 1.33 & 70.0 & 6.8 & 1.41 & 3.98 & 537 \\
\hline 08/29/11 09:10 & 1.42 & 70.0 & 7.2 & 1.38 & 4.14 & 696 \\
\hline 08/29/11 09:15 & 1.50 & 70.0 & 7.2 & 1.35 & 4.46 & 762 \\
\hline 08/29/11 09:18 & 1.55 & 70.0 & 7.3 & 1.32 & 4.74 & 788 \\
\hline 08/29/11 09:20 & 1.58 & 70.0 & 7.3 & 1.31 & 4.84 & 804 \\
\hline 08/29/11 09:22 & 1.62 & 70.0 & 7.2 & 1.31 & 4.99 & 816 \\
\hline 08/29/11 09:25 & 1.67 & 70.0 & 8.0 & 1.31 & 5.16 & 813 \\
\hline 08/29/11 09:27 & 1.70 & 70.0 & 8.0 & 1.30 & 5.27 & 815 \\
\hline 08/29/11 09:30 & 1.75 & 70.0 & 8.0 & 1.29 & 5.43 & 815 \\
\hline 08/29/11 09:32 & 1.78 & 70.0 & 8.0 & 1.29 & 5.55 & 816 \\
\hline 08/29/11 09:34 & 1.82 & 70.0 & 8.0 & 1.29 & 5.61 & 810 \\
\hline 08/29/11 09:36 & 1.85 & 70.0 & 8.0 & 1.29 & 5.72 & 807 \\
\hline 08/29/11 09:38 & 1.88 & 70.0 & 8.0 & 1.28 & 5.80 & 803 \\
\hline 08/29/11 09:40 & 1.92 & 70.0 & 8.0 & 1.28 & 5.87 & 800 \\
\hline 08/29/11 09:45 & 2.00 & 70.0 & 8.0 & 1.28 & 6.03 & 791 \\
\hline 08/29/11 09:50 & 2.08 & 70.0 & 8.0 & 1.27 & 6.09 & 788 \\
\hline 08/29/11 09:55 & 2.17 & 70.0 & 8.0 & 1.27 & 6.20 & 800 \\
\hline
\end{tabular}


Table A-3: Test 4 (Tank 5F Sludge) OA Batch 1 Decomposition Module Data

\begin{tabular}{|c|c|c|c|c|c|c|}
\hline $\begin{array}{c}\text { Date/Time } \\
\text { (mm/dd/yy hh:mm) }\end{array}$ & $\begin{array}{l}\text { Run Time } \\
\text { (hr) }\end{array}$ & $\begin{array}{c}\text { Temperature } \\
\left({ }^{\circ} \mathrm{C}\right)\end{array}$ & $\begin{array}{l}\text { Pressure } \\
\quad \text { (psi) }\end{array}$ & $\begin{array}{c}\text { Flow } \\
\text { (gal/min) }\end{array}$ & $\mathbf{p H}$ & $\begin{array}{l}\text { ORP } \\
(\mathrm{mV})\end{array}$ \\
\hline 08/29/11 10:00 & 2.25 & 70.0 & 8.0 & 1.27 & 6.36 & 769 \\
\hline 08/29/11 10:05 & 2.33 & 70.0 & 8.0 & 1.27 & 6.46 & 736 \\
\hline 08/29/11 10:10 & 2.42 & 70.0 & 8.0 & 1.27 & 6.60 & 698 \\
\hline 08/29/11 10:15 & 2.50 & 70.0 & 8.0 & 1.27 & 6.67 & 679 \\
\hline 08/29/11 10:20 & 2.58 & 70.0 & 7.9 & 1.27 & 6.78 & 669 \\
\hline 08/29/11 10:25 & 2.67 & 70.0 & 8.0 & 1.27 & 6.85 & 638 \\
\hline 08/29/11 10:30 & 2.75 & 70.0 & 8.1 & 1.27 & 6.95 & 634 \\
\hline 08/29/11 10:35 & 2.83 & 70.0 & 8.1 & 1.27 & 7.03 & 632 \\
\hline 08/29/11 10:40 & 2.92 & 70.0 & 8.1 & 1.27 & 7.10 & 613 \\
\hline 08/29/11 10:45 & 3.00 & 70.0 & 8.2 & 1.27 & 7.17 & 623 \\
\hline 08/29/11 10:55 & 3.17 & 70.0 & 8.2 & 1.27 & 7.38 & 615 \\
\hline 08/29/11 11:00 & 3.25 & 70.0 & 8.2 & 1.27 & 7.45 & 624 \\
\hline 08/29/11 11:05 & 3.33 & 70.0 & 8.2 & 1.27 & 7.55 & 637 \\
\hline 08/29/11 11:10 & 3.42 & 70.0 & 8.2 & 1.27 & 7.63 & 656 \\
\hline 08/29/11 11:15 & 3.50 & 70.0 & 8.2 & 1.27 & 7.74 & 600 \\
\hline 08/29/11 11:20 & 3.58 & 70.0 & 8.2 & 1.26 & 7.81 & 618 \\
\hline 08/29/11 11:25 & 3.67 & 70.0 & 8.2 & 1.26 & 7.86 & 637 \\
\hline 08/29/11 11:30 & 3.75 & 70.0 & 8.3 & 1.27 & 7.94 & 638 \\
\hline 08/29/11 11:36 & 3.85 & 70.0 & 8.4 & 1.25 & 8.05 & 657 \\
\hline 08/29/11 11:45 & 4.00 & 70.0 & 8.4 & 1.25 & 8.11 & 678 \\
\hline 08/29/11 12:00 & 4.25 & 70.0 & 8.5 & 1.25 & 8.22 & 677 \\
\hline 08/29/11 12:15 & 4.50 & 70.0 & 8.5 & 1.25 & 8.31 & 710 \\
\hline 08/29/11 12:30 & 4.75 & 70.0 & 8.5 & 1.25 & 8.38 & 733 \\
\hline 08/29/11 12:45 & 5.00 & 70.0 & 8.6 & 1.25 & 8.41 & 746 \\
\hline 08/29/11 13:07 & 5.37 & 70.0 & 8.8 & 1.25 & 8.45 & 760 \\
\hline 08/29/11 13:15 & 5.50 & 70.0 & 9.0 & 1.25 & 8.53 & 746 \\
\hline
\end{tabular}


Table A-4: Test 4 (Tank 5F Sludge) OA Batch 2 Decomposition Module Data

\begin{tabular}{|c|c|c|c|c|c|c|}
\hline $\begin{array}{c}\text { Date/Time } \\
\text { (mm/dd/yy hh:mm) }\end{array}$ & $\begin{array}{l}\text { Run Time } \\
\text { (hr) }\end{array}$ & $\begin{array}{c}\text { Temperature } \\
\left({ }^{\circ} \mathrm{C}\right)\end{array}$ & $\begin{array}{l}\text { Pressure } \\
\text { (psi) }\end{array}$ & $\begin{array}{c}\text { Flow } \\
\text { (gal } / \text { min) }\end{array}$ & pH & $\begin{array}{l}\text { ORP } \\
(\mathrm{mV})\end{array}$ \\
\hline 08/31/11 07:02 & -- & 26.6 & 0.0 & 1.50 & 1.15 & 215 \\
\hline 08/31/11 07:30 & -- & 56.2 & 0.0 & 1.50 & 1.09 & 148 \\
\hline 08/31/11 07:50 & 0.00 & 68.2 & 7.2 & 1.50 & 1.11 & 219 \\
\hline 08/31/11 08:00 & 0.17 & 70.9 & 7.0 & 1.50 & 1.13 & 256 \\
\hline 08/31/11 08:10 & 0.33 & 70.7 & 7.8 & 1.52 & 1.19 & 271 \\
\hline 08/31/11 08:20 & 0.50 & 70.0 & 7.3 & 1.52 & 1.22 & 274 \\
\hline 08/31/11 08:36 & 0.77 & 70.0 & 7.8 & 1.52 & 1.31 & 286 \\
\hline 08/31/11 08:45 & 0.92 & 70.0 & 8.0 & 1.52 & 1.39 & 289 \\
\hline 08/31/11 08:50 & 1.00 & 70.0 & 8.0 & 1.52 & 1.44 & 290 \\
\hline 08/31/11 08:58 & 1.13 & 70.0 & 8.0 & 1.52 & 1.67 & 313 \\
\hline 08/31/11 09:00 & 1.17 & 70.0 & -- & 1.52 & 1.88 & 327 \\
\hline 08/31/11 09:02 & 1.20 & 70.0 & 8.0 & 1.52 & 3.13 & 327 \\
\hline 08/31/11 09:04 & 1.23 & 69.9 & 8.0 & 1.53 & 3.54 & 353 \\
\hline 08/31/11 09:06 & 1.27 & 69.9 & 7.9 & 1.53 & 3.44 & 407 \\
\hline 08/31/11 09:08 & 1.30 & 69.8 & 8.0 & 1.53 & 3.31 & 730 \\
\hline 08/31/11 09:11 & 1.35 & 69.9 & 8.0 & 1.53 & 3.45 & 844 \\
\hline 08/31/11 09:16 & 1.43 & 69.9 & 8.0 & 1.37 & 3.65 & 812 \\
\hline 08/31/11 09:22 & 1.53 & 70.0 & 8.0 & 1.35 & 4.33 & 858 \\
\hline 08/31/11 09:25 & 1.58 & 70.0 & 8.0 & 1.33 & 4.85 & 845 \\
\hline 08/31/11 09:27 & 1.62 & 70.0 & 8.2 & 1.33 & 5.15 & 864 \\
\hline 08/31/11 09:30 & 1.67 & 70.0 & 8.0 & 1.33 & 5.36 & 864 \\
\hline 08/31/11 09:33 & 1.72 & 70.0 & 8.0 & 1.33 & 5.54 & 877 \\
\hline 08/31/11 09:35 & 1.75 & 70.0 & 8.0 & 1.32 & 5.71 & 880 \\
\hline 08/31/11 09:37 & 1.79 & 70.0 & 8.0 & 1.32 & 5.88 & 852 \\
\hline 08/31/11 09:40 & 1.83 & 70.0 & 8.3 & 1.32 & 6.07 & 855 \\
\hline 08/31/11 09:45 & 1.92 & 70.0 & 8.0 & 1.32 & 6.35 & 860 \\
\hline 08/31/11 09:50 & 2.00 & 69.9 & 8.1 & 1.32 & 6.69 & 848 \\
\hline 08/31/11 09:55 & 2.08 & 70.0 & 8.5 & 1.32 & 6.93 & 843 \\
\hline 08/31/11 10:00 & 2.17 & 70.0 & 7.5 & 1.31 & 7.14 & 842 \\
\hline 08/31/11 10:05 & 2.25 & 70.0 & 8.0 & 1.31 & 7.43 & 825 \\
\hline 08/31/11 10:10 & 2.33 & 70.0 & 8.2 & 1.30 & 7.60 & 836 \\
\hline 08/31/11 10:15 & 2.42 & 70.0 & 7.2 & 1.32 & 7.40 & 834 \\
\hline 08/31/11 10:20 & 2.50 & 70.0 & 7.5 & 1.32 & 7.68 & 830 \\
\hline 08/31/11 10:25 & 2.58 & 70.0 & 7.9 & 1.30 & 7.87 & 829 \\
\hline
\end{tabular}


SRNL-STI-2011-00751

Revision 0

Table A-4: Test 4 (Tank 5F Sludge) OA Batch 2 Decomposition Module Data

\begin{tabular}{c|c|c|c|c|c|c}
\hline $\begin{array}{c}\text { Date/Time } \\
(\mathbf{m m} / \mathbf{d d} / \mathbf{y y} \mathbf{h h}: \mathbf{m m})\end{array}$ & $\begin{array}{c}\text { Run Time } \\
\mathbf{( h r})\end{array}$ & $\begin{array}{c}\text { Temperature } \\
\mathbf{(} \mathbf{} \mathbf{C})\end{array}$ & $\begin{array}{c}\text { Pressure } \\
\mathbf{( p s i )}\end{array}$ & $\begin{array}{c}\text { Flow } \\
\text { (gal/min) }\end{array}$ & pH & $\begin{array}{c}\text { ORP } \\
(\mathbf{m V})\end{array}$ \\
\hline $08 / 31 / 1110: 30$ & 2.67 & 70.0 & 8.1 & 1.30 & 7.95 & 825 \\
\hline $08 / 31 / 1110: 35$ & 2.75 & 70.0 & 8.1 & 1.30 & 8.03 & 824 \\
\hline $08 / 31 / 1110: 40$ & 2.83 & 70.0 & 7.0 & 1.26 & 7.78 & 841 \\
\hline $08 / 31 / 1110: 45$ & 2.92 & 70.0 & 7.5 & 1.30 & 7.94 & 825 \\
\hline $08 / 31 / 1111: 00$ & 3.17 & 70.0 & 8.0 & 1.30 & 8.23 & 822 \\
\hline $08 / 31 / 1111: 15$ & 3.42 & 70.0 & 8.1 & 1.30 & 8.32 & 818 \\
\hline $08 / 31 / 1111: 30$ & 3.67 & 70.0 & 8.3 & 1.30 & 8.35 & 819 \\
\hline $08 / 31 / 1111: 45$ & 3.92 & 70.0 & 8.5 & 1.31 & 8.38 & 818 \\
\hline $08 / 31 / 1112: 00$ & 4.17 & 70.0 & 8.5 & 1.31 & 8.42 & 809 \\
\hline $08 / 31 / 1112: 15$ & 4.42 & 70.0 & 8.7 & 1.32 & 8.41 & 828 \\
\hline
\end{tabular}

